DOI https://doi.org/10.30525/978-9934-26-008-7.1-7

\title{
НЕОРГАНИЧЕСКИЕ АНИОНООБМЕННЫЕ МАТЕРИАЛЫ НА ОСНОВЕ ГИДРАТИРОВАННОГО ОКСИДА АЛЮМИНИЯ
}

\author{
Кудрявцев П. Г.
}

\section{ВВЕДЕНИЕ}

Использование гидрометаллургических переделов в цветной металлургии часто затрудняется из-за присутствия в производственных растворах ионных примесей, нарушающих нормальный ход процессов, например, при электрохимическом осаждении или цементации металлов, выщелачивании промышленных продуктов (вельц-оксиды, шлаки, возгоны, свинцовые пыли и другие), разделении жидкой и твердой фаз ${ }^{1}$. Для этих целей обычно применяются такие приемы понижения содержания примесей в электролитах, как осаждение в виде малорастворимого соединения, водно-щелочная промывка или прокаливание промышленных продуктов перед растворением. Однако эти приемы не всегда позволяют получить результаты, которые удовлетворяют требованиям современной технологии. Главной причиной такой ситуации является низкая избирательность извлечения, невысокая глубина очистки, возникновение больших объемов трудно фильтруемых суспензий и твердых отходов. Перечисленные недостатки практически отсутствуют у сорбционных методов извлечения примесей из растворов ${ }^{2}$. Однако применительно к цветной металлургии данные методы разработаны в основном для выделения из растворов примесей, которые находятся в катионной форме, а не в виде анионов ${ }^{3}$. Одной из причин сложившейся ситуации является сравнительно узкий ассортимент выпускаемых марок анионитов, пригодных для селективной очистки от анионов сложных по составу электролитов. Возможности сорбционных методов очистки

${ }^{1}$ Хабаши Ф. Основы прикладной металлургии. Т. 2. Москва : Металлургия, 1975.

2 Иониты в химической технологии. Под ред. Никольского Б. П. и Романкова П. Г. Ленинград: Химия, 1982.

3 Лебедев К.В., Казанцев Е.Я., Розманов В.М. и др. Иониты в цветной металлургии. Москва : Металлургия, 1975. 
растворов значительно расширяются при использовании наряду с ионообменными смолами неорганических сорбентов ${ }^{4}$. Причем для извлечения из растворов анионов наиболее перспективным представляется применение в качестве сорбентов материалов на основе гидратированных оксидов металлов ${ }^{5,6}$.

Неорганические сорбенты по сравнению е обычными органическими ионитами обладают более высокой селективностью, радиационной, термической и химической устойчивостью ${ }^{7,8}$. Однако практика выдвигает вое новые требовании по дальнейшему увеличению устойчивости неорганических сорбентов в растворах кислот и щелочей, в особых гидротермических условиях, по дальнейшему повышению их обменной емкости, по упрощении и удешевлению процессов синтеза, по обеспечение хорошей воспроизводимости свойств. Высокие и разнообразные требования к сорбентам можно удовлетворить лишь путем создания технологии целенаправленного их синтеза, направленного на получение сорбентов с управляемым набором свойств. Решение этой проблемы возможно при условии всестороннего изучения химического строения и реакционной способности соответствующих материалов.

Среди известных в настоящее время неорганических сорбентов важное место занимают малорастворимые кислородные соединения различных элементов. В их числе важный теоретический интерес и практическое значение имеет класс гидратированных оксидов многовалентных металлов. Многие работы, выполненные в России и за рубежом и посвященные исследованию сорбционных свойств гидратированных оксидов, выявлены их хорошие ионообменные свойства. При этом проведенные исследования позволили получить первые доказательства возможности модифицирования их структуры и свойств под действием различных факторов. Таким образом, гидратированные оксиды металлов можно рассматривать в

4 Вольхин В.В., Леонтьева Г.В. Физико-химическое исследование ионообменных свойств двуокиси марганца. Извести АН СССР. Серия: Неорганические материалы. 1969, т. 5, № 7, с. 1224-19.

${ }_{6}^{5}$ См. сноску 4.

6 Вольхин В.В., Леонтьева Г.В. Физико-химическое исследование ионообменных свойств двуокиси марганца. Извести АН СССР. Серия: Неорганические материалы. 1969, т. 5, № 7, с. 1224-19.

${ }^{7}$ Амфлетт Ч. Неорганические иониты. Москва : МИР, 1966, 188 с.

${ }^{8}$ Степин Б.Д. Методы получения особо чистых неорганических веществ. Ленинград : Химия, 1969. 
качестве универсальной основы при синтезе ионообменных материалов, обладающих определенным набором свойств.

Определяющая роль структуры твердой фазы для достижения заданных ионообменных свойств показана для материалов, синтезированных на основе гидратированных оксидов марганца(IV), сурьмы(V) и титана(IV $)^{9,10,11}$. Но ограниченный круг исследованных объектов пока не позволяет сформулировать общие положения, описывающие связь ионообменных свойств, условий получения структуры гидратированных оксидов. Дополнительные трудности на этом пути обусловлены аморфным характером гидратированных оксидов, который предопределяет разногласия в структурных моделях, предложенных разными авторами, а чаще всего и полное их отсутствие.

Одним из новых путей изменения свойств гидратированных оксидов является введение в их структуру добавок посторонних ионов $^{12}$. Тем не менее в опубликованных работах практически не оценивалась эффективность введения добавок различных по валентности металлов для широкого круга гидратированных оксидов. Прежде всего, в имеющихся работах не было выявлено влияние добавок на структуру используемых веществ. Такая ситуация не позволяет делать надежные прогнозы по их влиянию и на ионообменные свойства синтезируемых материалов. Исключение составляют только работы по введению добавок в неорганические ионообменные материалы со шпинельной структуры ${ }^{13}$. Все это сдерживает разработку методов целенаправленного синтеза неорганических ионообменных материалов и не позволяет широко использовать легирование для дальнейшего улучшения их свойств.

9 Вольхин В.В., Леонтьева Г.В. Физико-химическое исследование ионообменных свойств двуокиси марганца. Извести АН СССР. Серия: Неорганические материалы. 1969, т. 5, № 7, с. 1224-19.

10 Белинская Ф.А., Милицина Э.А. Неорганические ионообменные материалы на основе труднорастворимых соединений сурьмы (V). Усnехи химии. 1980 , т. 49, № 10, с. 1904-1936.

${ }^{11}$ Онорин С.А., Вольхин В.В., Ходяшев М.Б., Сесюнина Е.А., Алпатова Е.В. Свойства композиционных титансодержащих сорбентов. Межвузовский сборник научных трудов: Химия и технология неорганических сорбентов. Пермь : 1989 , с. 124-129.

12 Вольхин В.В., Леонтьева Г.В. Физико-химическое исследование ионообменных свойств двуокиси марганца. Извести АН СССР. Серия: Неорганические материалы. 1969, т. 5, № 7, с. 1224-19.

${ }^{13}$ См. сноску 12. 
В связи с решением задачи модифицированная материалов за счет введения добавок дополнительных ионов в их фазу возникла необходимость разработки способов осуществления этого процесса.

Однако само по себе одностороннее изучение влияния добавок элементов на ионообменные свойства синтезируемых материалов не дает всей полноты информации о механизме и закономерностях их влияния. Знание строения соответствующих смешанных материалов и состояния входящих в их структуру ионов добавок позволит решить задачу прогнозирования влияния различных добавок на свойства гидратированных оксидов. Работая над созданием методов целенаправленного синтеза ионообменных материалов, можно предвидеть, что сделанные рекомендации будут полезны не только для получения ионообменников, но также для синтеза на основе смешанных оксидов широкого круга неорганических материалов с различными ценными свойствами (электрофизическими, каталитическими, огнеупорными и так далее).

В соответствии с намеченными путями решения указанной проблемы, целью настоящего исследования явилось развитие физико-химических основ метода направленного синтеза ионообменных материалов. В качестве основы для синтеза таких материалов выбраны гидратированных оксидов и, в частности, гидратированный оксид алюминия. В связи с этим одной из целей этого исследования явилось установление взаимосвязи структуры и ионообменных свойств выбранных материалов, включая применение методов модифицирования их структуры, за счет введения добавок.

Неорганические ионообменники являются универсальными материалами, проявляющими как катионообменные, так и анионообменные свойства. Большое количество работ в этой области посвящено в основном синтезу и применению неорганических катионообменных материалов. При этом изученность процессов анионного обмена и синтез неорганических анионообменников значительно отстают от развития исследований в области получения катионообменных материалов.

Ранее нами обсуждались результаты синтеза и производственных испытаний неорганического анионообменника на основе оксигидрата титана, предназначенного для очистки от мышьяка 
цинк-кадмиевых растворов $^{14,15}$. В данной работе на примере гидратированного оксида алюминия (ГОА) исследуется возможность расширения круга оксигидратов металлов, способных служить основой для получения неорганических анионообменных материалов. Ранее нами были разработаны способы получения неорганических анионообменников на основе гидратированного оксида алюминия, легированного ионами $\mathrm{W}(\mathrm{VI}), \mathrm{Zr}(\mathrm{IV})$ и $\mathrm{Ti}(\mathrm{IV})$. Синтезированным материалам были присвоены условные символы соответственно ААВ-0, ААЦ-0 и ААТ-0 16,17,18,19,20. Настоящая работа посвящена изучению влияния различных факторов на строение и ионообменный свойства получаемых материалов.

\section{1. Гидролиз соединений алюминия}

Основной стадией синтеза ионообменных материалов на основе гидратированных оксидов является гидролиз соответствующих солей металлов. Механизм процесса гидролиза солей металлов весьма сложен и зависит от большого числа внешних факторов, таких как состав растворов, температура, скорость взаимодействия компонентов, характер их смешения и т. д. В нашей предыдущей работе $^{21}$ мы детально рассматривали вопросы синтеза коллоидных

${ }^{14}$ Ходящев М.Б., Онорин С. А., Вольхин В. В. и др. Переработка твердых отходов производства оксида ванадия (V) из технического окситрихлорида ванадия. Цветные металлы. 1985. № 4. С. 66.

15 Ходяшев М.Б., Онорин С.А., Вольхин В.В. и др. Сорбционная очистка цинк-кадмиевых растворов от мышьяка. Цветные металлы. 1987. № 2. С. 22.

16 Кудрявцев П.Г., Онорин С.А., Вольхин В.В. Способ получения неорганического анионообменника. А.с. № 1125043 (СССР) Опубл. в Б. И. 1984. № 43. С. 33 .

17 Кудрявцев П.Г., Онорин С.А., Вольхин В.В. Способ получения неорганического анионообменника. А.с. № 1189497 (СССР) Опубл. в Б. И. 1985. № 41. С. 30.

18 Кудрявцев П.Г., Онорин С.А., Вольхин В.В. Способ получения неорганического анионообменника. А.с. № 1274763 (СССР) Опубл. в Б. И. 1986. № 45. С. 28

${ }_{19}$ Кудрявцев П.Г. Онорин С.А. Способ получения неорганического анионообменника ААТ-1. А.С. СССР № 1435280 по заявке № 4227940 от 13.04 .87

20 Кудрявцев П.Г. Онорин С.А., Вольхин В.В. Способ получения неорганического анионообменника. А.С. СССР № 1435281 по заявке № 4228474 от 13.04 .87

${ }^{21}$ Muller D., D. Hoebbel D., Gessner W. 27Al NMR studies of aluminosilicate solutions. Influences of the second coordination sphere on the shielding of aluminium Chemical Physics Letters, Volume 84, Issue 1, 15 November 1981, Pages 25-29, doi:10.1016/0009-2614(81)85362-6. 
растворов гидратированного оксида алюминия. Многие факторы, оказывающие влияние на процесс синтеза коллоидных растворов, также актуальны при получении ионообменных материалов на основе гидратированных оксидов. Их синтез также осуществляется с использованием золь-гель процессов. В связи с этим необходимо рассмотреть такой важный вопрос, как состояние алюминия в водных растворах на различных стадиях процесса гидролиза с образованием гидратированного оксида алюминия.

В работах ${ }^{22,23}$ представлены результаты расчетов констант растворения, констант прочности и свободной энергии Гиббса для различных гидратных комплексов алюминия. Константы равновесия реакций образования соответствующих ионов были рассчитаны с использованием полученных значений.

Как указано, растворимость этих оксидных и гидроксидных фаз алюминия важна при производстве алюминия при повышенной температуре и различных значениях $\mathrm{pH}$, в том числе в тех условиях, где преобладает образование анионных продуктов гидролиза, таких как $\left[\mathrm{Al}\left(\mathrm{H}_{2} \mathrm{O}\right)_{2}(\mathrm{OH})_{4}\right]^{-}$и $\left[\mathrm{Al}(\mathrm{OH})_{6}\right]^{3-}$. Также известно, что образуются другие гидролизованные мономерные частицы алюминия, начиная от $[\mathrm{Al}(\mathrm{OH})]^{2+}$ до $\mathrm{Al}(\mathrm{OH})_{3} \cdot(\mathrm{aq})$. В работе ${ }^{24}$ более концентрированных растворах солей алюминия в были идентифицированы некоторые полимерные виды продуктов гидролиза алюминия, включая $\left[\mathrm{Al}_{2}(\mathrm{OH})_{2}\right]^{4+}, \quad\left[\mathrm{Al}_{3}(\mathrm{OH})_{4}\right]^{5+}$ и $\left[\mathrm{Al}_{13}(\mathrm{OH})_{32}\right]^{7+}$ (или, точнее, $\left.\left[\mathrm{Al}_{12}\left(\mathrm{AlO}_{4}\right)(\mathrm{OH})_{24}\left(\mathrm{H}_{2} \mathrm{O}\right)_{12}\right]^{7+25}\right)$. Реакция, описывающая образование этих видов, дается формулой:

$$
p A l^{3+}+q \mathrm{H}_{2} \mathrm{O} \leftrightarrow A l_{p}(\mathrm{OH})_{3 \cdot p-q}+q H^{+}
$$

22 Brown P.L., Ekberg C. Hydrolysis of Metal Ions. Volume 1-2, Wiley-VCH, 2016, 945 p. ISBN: 978-3-527-65621-9.

${ }^{23}$ Wesolowski D.J., Palmer D.A. Aluminum speciation and equilibria in aqueous solution: V. Gibbsite solubility at $50^{\circ} \mathrm{C}$ and $\mathrm{pH} 3-9$ in 0.1 molal $\mathrm{NaCl}$ solutions (a general model for aluminum speciation; analytical methods). Geochimica et Cosmochimica Acta, Vol. 58, No. 14, pp. 2947-2969, 1994. URL: https://doi.org/10.1016/0016-7037(94)90171-6.

${ }^{24}$ См. сноску 22.

${ }^{25}$ Shafran, K. L., Deschaume, O., \& Perry, C. C. The static anion exchange method for generation of high purity aluminium polyoxocations and monodisperse aluminium hydroxide nanoparticles. Journal of Materials Chemistry, 2005, 15(33), 3415. doi:10.1039/b505466d. 
На основе этих данных рассчитана зависимость относительной доли гидроксокомплексов алюминия $\beta_{i}$ от $\mathrm{pH}$ раствора, которая представлена на рисунке 1. Анализ полученных данных показывает, какие гидроксокомплексы алюминия существует при заданном значении $\mathrm{pH}$. Так, например, при $\mathrm{pH}=12$ преимущественно существует только ион $\mathrm{Al}(\mathrm{OH})_{6}^{3-}, \quad$ а гидроксокомплекс $\mathrm{Al}\left(\mathrm{H}_{2} \mathrm{O}\right)_{3}(\mathrm{OH})_{3}$, проявляющий минимальную растворимость, будет существовать примерно при $\mathrm{pH}=6 \div 8$.

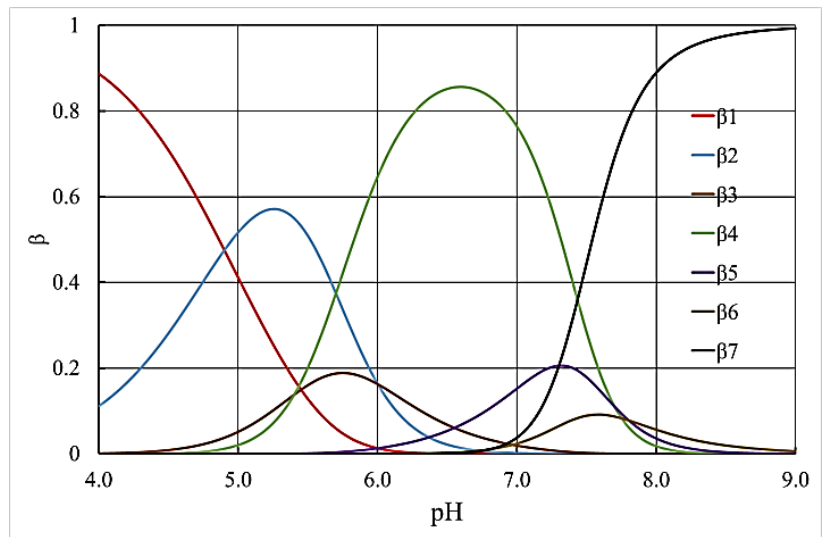

Рис. 1. Зависимость относительной доли гидроксокомплексов алюминия $\beta_{i}$ в водном растворе от $\mathrm{pH} . \boldsymbol{\beta}_{1}-\left[\mathrm{Al}\left(\mathrm{H}_{2} \mathrm{O}\right)_{6}\right]^{3+}$; $\beta_{2}-\left[\mathrm{Al}\left(\mathrm{H}_{2} \mathrm{O}\right)_{5} \mathrm{OH}\right]^{2+} ; \beta_{3}-\left[\mathrm{Al}\left(\mathrm{H}_{2} \mathrm{O}\right)_{4}(\mathrm{OH})_{2}\right]^{+} ; \beta_{4}-\mathrm{Al}(\mathrm{OH})_{3} \cdot(\mathbf{a q}) ;$ $\beta_{5}-\left[\mathrm{Al}\left(\mathrm{H}_{2} \mathrm{O}\right)_{2}(\mathrm{OH})_{4}\right]^{-} ; \boldsymbol{\beta}_{6}-\left[\mathrm{Al}\left(\mathrm{H}_{2} \mathrm{O}\right)(\mathrm{OH})_{5}\right]^{2-} ; \beta_{7}-\left[\mathrm{Al}(\mathrm{OH})_{6}\right]^{3-}$

Данные рисунка 1 удобнее представить в виде диаграммы Брауна и Экберга ${ }^{26}$, на которой представлены области существования ионов алюминия(III) вида $\mathrm{Al}\left(\mathrm{H}_{2} \mathrm{O}\right)_{6-n}(\mathrm{OH})_{n}^{(3-n)-}$ в зависимости от $\mathrm{pH}$ и концентрации соединений алюминия (рисунок 2).

${ }^{26}$ Brown P.L., Ekberg C. Hydrolysis of Metal Ions. Volume 1-2, Wiley-VCH, 2016, 945 p. ISBN: 978-3-527-65621-9 


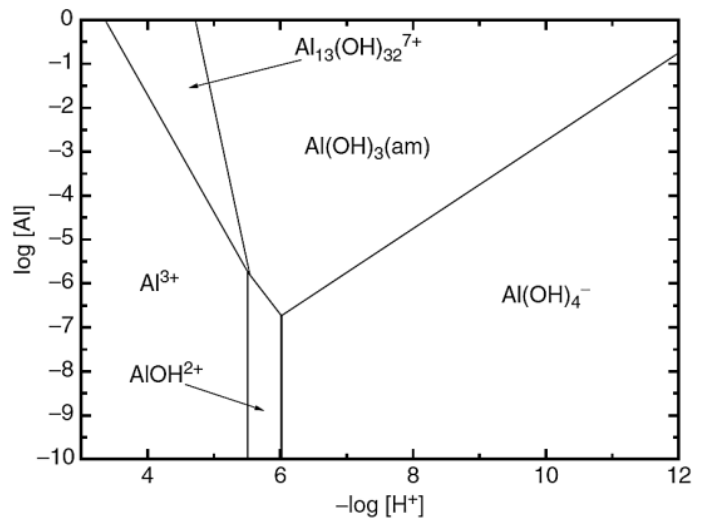

Рис. 2. Диаграмма Брауна и Экберга ${ }^{27}$ для областей существования ионов алюминия(III) вида $\mathrm{Al}\left(\mathrm{H}_{2} \mathrm{O}\right)_{6-n}(\mathrm{OH})_{n}^{(3-n)-}$, при $25^{\circ} \mathrm{C}$ и ионной силой 1,0 моль $2^{-1}$ хлорида натрия, в зависимости от концентрации алюминия и рН среды. В качестве твердой фазы использован $\mathrm{Al}(\mathrm{OH})_{3(\text { am })}\left(\lg \mathrm{K}_{\mathrm{s10}}=10,80\right)$

Проведен расчет зависимости растворимости $\mathrm{Al}_{2} \mathrm{O}_{3}$ от $\mathrm{pH}$, для этого были рассмотрены следующие реакции взаимодействия $\mathrm{Al}_{2} \mathrm{O}_{3}$ с образованием различных ионов алюминия:

$$
\begin{gathered}
\mathrm{Al}_{2} \mathrm{O}_{3}+6 \mathrm{H}^{+} \rightarrow 2 \mathrm{Al}\left(\mathrm{H}_{2} \mathrm{O}\right)_{6}^{3+}+3 \mathrm{H}_{2} \mathrm{O} \\
\mathrm{Al}_{2} \mathrm{O}_{3}+4 \mathrm{H}^{+} \rightarrow 2 \mathrm{Al}(\mathrm{OH})\left(\mathrm{H}_{2} \mathrm{O}\right)_{5}^{2+}+\mathrm{H}_{2} \mathrm{O} \\
\mathrm{Al}_{2} \mathrm{O}_{3}+2 \mathrm{H}^{+}+\mathrm{H}_{2} \mathrm{O} \rightarrow 2 \mathrm{Al}(\mathrm{OH})\left(\mathrm{H}_{2} \mathrm{O}\right)_{5}^{2+} \\
\mathrm{Al}_{2} \mathrm{O}_{3}+3 \mathrm{H}_{2} \mathrm{O} \rightarrow 2 \mathrm{Al}(\mathrm{OH})_{3}\left(\mathrm{H}_{2} \mathrm{O}\right)_{3} \\
\mathrm{Al}_{2} \mathrm{O}_{3}+5 \mathrm{H}_{2} \mathrm{O} \rightarrow 2 \mathrm{Al}(\mathrm{OH})_{4}\left(\mathrm{H}_{2} \mathrm{O}\right)_{2}^{-}+2 \mathrm{H}^{+} \\
\mathrm{Al}_{2} \mathrm{O}_{3}+7 \mathrm{H}_{2} \mathrm{O} \rightarrow 2 \mathrm{Al}(\mathrm{OH})_{5}\left(\mathrm{H}_{2} \mathrm{O}\right)^{2-}+4 \mathrm{H}^{+} \\
\mathrm{Al}_{2} \mathrm{O}_{3}+9 \mathrm{H}_{2} \mathrm{O} \rightarrow 2 \mathrm{Al}(\mathrm{OH})_{6}^{3-}+6 \mathrm{H}^{+}
\end{gathered}
$$

Для каждой реакции рассчитана зависимость логарифма растворимости от $\mathrm{pH}$ и получена суммарная кривая. Данные зависимости представлены на рисунке 3 .

${ }^{27}$ Brown P.L., Ekberg C. Hydrolysis of Metal Ions. Volume 1-2, Wiley-VCH, 2016, 945 p. ISBN: 978-3-527-65621-9 


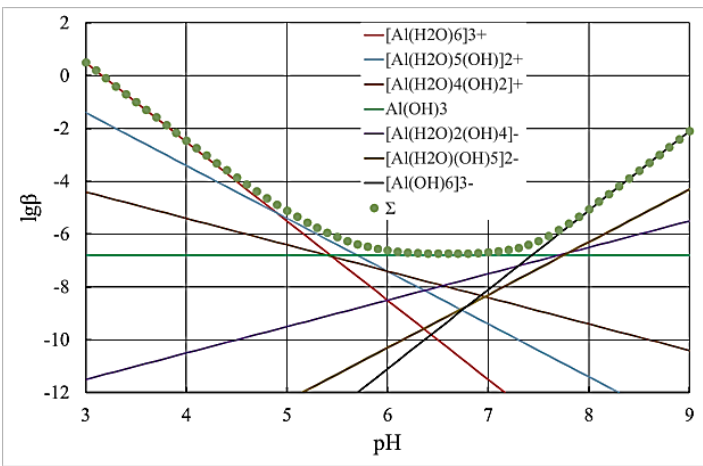

\section{Рис. 3. Зависимость логарифма растворимости $\mathrm{Al}_{2} \mathrm{O}_{3}(\operatorname{lgS})$ от $\mathrm{pH}$}

Полученные данные показывают, что при $\mathrm{pH}=6,7$ наблюдается минимальная растворимость. Это значение $\mathrm{pH}$ соответствует точке нулевого заряда $-\mathrm{pH}_{\text {тнз }}$, что соответствует отсутствию заряда на поверхности частиц $\mathrm{Al}_{2} \mathrm{O}_{3}$.

При $\mathrm{pH}<\mathrm{pH}_{\text {тнз }}$ частицы $\mathrm{Al}_{2} \mathrm{O}_{3}$ имеют положительный заряд, а при $\mathrm{pH}>\mathrm{pH}_{\text {тнз }}-$ отрицательный заряд. Этот заряд обусловлен как

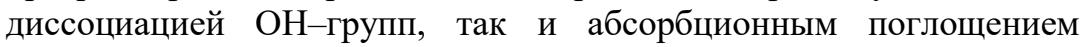
свободных $\mathrm{OH}^{-}$-ионов. Максимальная скорость формирования твердой фазы гидратированного оксида алюминия, соответственно, будет наблюдаться в точке нулевого заряда $\left(\mathrm{pH}_{\text {тнз }}\right)$.

Полученные теоретические выводы в целом хорошо согласуются с экспериментальными данными. Таким образом, понижая $\mathrm{pH}$ раствора различными методами (в том числе электродиализом), можно добиться максимально полного осаждения гидроксида алюминия. Однако в некоторых источниках существуют противоречивые данные о величине $\mathrm{pH}_{\text {тнз }}$ у гидратированных оксидов алюминия. Этот факт связан с различными методами его получения и, соответственно, с различной структурой его поверхности.

В работе ${ }^{28}$ проведены измерения рэлеевской мутности растворов гидролизованного алюминия, содержащих различное количество связанных ионов гидроксида на один ион алюминия. При этом показано образование многоядерных комплексов алюминия. Обнаружено, что до начала осаждения размер образующихся

${ }^{28}$ Patterson H., Tyree Jr. S.Y. A light scattering study of the hydrolytic polymerization of aluminum. Journal of Colloid and Interface Science, Vol. 43, N 2, 1973, P. 389-398. URL: https://doi.org/10.1016/0021-9797(73)90385-8. 
многоядерных гидроксокомплексов достигает минимум восьми или девяти атомов алюминия на один изополикатион. Маловероятно, что какие-либо растворы, кроме тех, которые имеют соотношение $\mathrm{OH} / \mathrm{Al}=1,0$, соответствуют условиям равновесия.

Исходя из представленных данных, можно сделать предположение о том, что большое влияние на свойства получаемого гидроксида алюминия будет оказывать метод его синтеза. В частности, свойства должны зависеть от порядка и скорости сливания реагентов. Так, при вливании раствора щелочи в раствор соли алюминия (прямой порядок синтеза) предпочтительно должны образовываться структуры, имеющие избыточный положительный заряд, и соответственно более склоненные к анионному обмену. В случае вливания раствора соли алюминия в раствор щелочи предварительно образуются анионные формы гидратированного оксида алюминия, которые приводят к формированию структур с избыточным отрицательным зарядом. Такие структуры должны быть более склонны к катионному обмену. Увеличение скорости взаимодействия растворов реагентов должно приводить к формированию метастабильных форм, соответствующих первоначальному строению оксигидратных ионов алюминия. Дальнейшее старение образованных осадков должно изменять их структуру, однако этот процесс может быть весьма затруднен медленной скоростью протекания процессов массопереноса в сформированной твердой фазе.

Этот эффект нашел подтверждение в работах ${ }^{29,30}$, где сообщается, что раствор $1 \mathrm{M}$ солей алюминия при $1<\mathrm{OH} / \mathrm{Al}<2,5$ требует примерно 6 месяцев для уравновешивания равновесия при комнатной температуре и примерно 1 час при $70^{\circ} \mathrm{C}$. Данные малоуглового рассеяния рентгеновских лучей показывают образование катионов $\left[\mathrm{Al}_{12}\left(\mathrm{AlO}_{4}\right)(\mathrm{OH})_{24}\left(\mathrm{H}_{2} \mathrm{O}\right)_{12}\right]^{7+}$, хотя при этом нельзя исключать образования некоторого количества и более мелких единиц. Другими видами растворенных веществ, которые

29 Patterson H., Tyree Jr. S.Y. A light scattering study of the hydrolytic polymerization of aluminum. Journal of Colloid and Interface Science, Vol. 43, N 2, 1973, P. 389-398. URL: https://doi.org/10.1016/0021-9797(73)90385-8

${ }^{30}$ Rausch, W.V. and Bale, H.D. Small angle X-ray scattering from hydrolyzed aluminum nitrate solutions: J. Chem. Phys. 1964, 40, 3391-3394. URL: https://doi.org/10.1063/1.1725011. 
были предложены для объяснения данных, являются $\left[\mathrm{Al}_{8}(\mathrm{OH})_{20}\right]^{4+31}$; $\left[\mathrm{Al}_{4}(\mathrm{OH})_{10}\right]^{2+} ; \quad\left[\mathrm{Al}_{4}(\mathrm{OH})_{8}\right]^{4+}, \quad\left[\mathrm{Al}_{7}(\mathrm{OH})_{16}\right]^{5+}, \quad\left[\mathrm{Al}_{10}(\mathrm{OH})_{24}\right]^{6+}$, $\left[\mathrm{Al}_{3}(\mathrm{OH})_{32}\right]^{7+}{ }^{32} ; \quad\left[\mathrm{A} 1_{6}(\mathrm{OH})_{15}\right]^{3+} ; \quad\left[\mathrm{A} 1_{6}(\mathrm{OH})_{13}\right]^{5+}{ }^{33,34}$. Также было замечено, что природа исходного катиона в растворе определяет форму гидроксида алюминия, который в дальнейшем кристаллизуется из раствора (гидраргиллит или байерит) $)^{35}$.

Стехиометрия комплексного иона $\left[\mathrm{Al}_{12}\left(\mathrm{AlO}_{4}\right)(\mathrm{OH})_{24}\left(\mathrm{H}_{2} \mathrm{O}\right)_{12}\right]^{7+}$ была подтверждена рентгеновскими исследованиями ${ }^{36,37}$. Это исследование показало, что данный комплексный ион имеет формулу $\left[\mathrm{Al}_{12}\left(\mathrm{AlO}_{4}\right)(\mathrm{OH})_{24}\left(\mathrm{H}_{2} \mathrm{O}\right)_{12}\right]^{7+}$ эквивалентную $\left[\mathrm{Al}_{13}(\mathrm{OH})_{32}\right]^{7+}$. В данной разновидности комплексных ионов 12 атомов алюминия находятся в центрах 12 кислородных октаэдров $\mathrm{AlO}_{6}$, а один атомом алюминия расположен в алюмокислородном тетраэдре $\mathrm{AlO}_{4}$. В его структуре, представленной на рисунке $4 \mathrm{a}$, есть также 12 молекул воды, связанных с ионами $\mathrm{Al}^{3+38,39}$. Такие ионы имеют структуру Кеггина. Аналогичная структура была идентифицирована у очень стабильного смешанного металлогидроксидного соединения с

${ }^{31}$ Matijević E., Mathai K.G., Ottewill R.H., Kerker M. Detection of Metal Ion Hydrolysis by Coagulation. III. Aluminum. J. Phys. Chem. 1961, 65, 5, 826-830. URL: https://doi.org/10.1021/j100823a028.

${ }^{32}$ Van Cauwelaert, F. H., Bosmans, H. J. Polycations formed in the hydrolysis of the aluminum ion. J. Rev. Chim. Minerale, 1969, Vol. 6, No 3, p. 611-623.

33 Leonard A.J., Van Cauwelaert P., Fripiat J.J. Structure and properties of amorphous silicoaluminas. III. Hydrated aluminas and transition aluminas // J.Phys.Chem. 1967. V. 71, № 3. P. 695-708.

${ }^{34}$ См. сноску 30.

35 Wefers, K. Oxides and Hydroxides of Aluminum. Naturwissenschaflen, 49, 204-205 (1962).

36 Brown P.L., Ekberg C. Hydrolysis of Metal Ions. Volume 1-2, Wiley-VCH, 2016, 945 p. ISBN: 978-3-527-65621-9

37 Shafran, K. L., Deschaume, O., \& Perry, C. C. The static anion exchange method for generation of high purity aluminium polyoxocations and monodisperse aluminium hydroxide nanoparticles. Journal of Materials Chemistry, 2005, 15(33), 3415. doi:10.1039/b505466d.

38 Johansson, G. (1960) On the crystal structures of some basic aluminium salts. Acta Chem. Scand., 14, 771-773.

${ }^{39}$ Shafran, K. L., Deschaume, O., \& Perry, C. C. The static anion exchange method for generation of high purity aluminium polyoxocations and monodisperse aluminium hydroxide nanoparticles. Journal of Materials Chemistry, 2005, 15(33), 3415. doi:10.1039/b505466d. 
формулой $\left[\mathrm{GaO}_{4}\right]\left[\mathrm{Al}_{12}(\mathrm{OH})_{24}\right]^{7+} 40$. Это смешанное соединение четко демонстрирует ту же структуру, что и у ионов, содержащих только алюминий. В работе ${ }^{41}$ было обнаружено образование еще более крупного катиона со структурным мотивом Кеггина $\left[\mathrm{Al}_{30} \mathrm{O}_{8}(\mathrm{OH})_{56}\left(\mathrm{H}_{2} \mathrm{O}\right)_{26}\right]^{18+}$. Структура такого катиона представлена на рисунке 4 б.

Гидроксид алюминия $\mathrm{Al}(\mathrm{OH})_{3}$, часто встречающихся в виде гелеобразного материала. В кристаллической форме его получают путем подачи $\mathrm{CO}_{2}$ в щелочной раствор алюмината щелочного металла, при $80^{\circ} \mathrm{C}$. В природе гидроксид алюминия встречается чаще всего в виде гиббсита, а также и в виде других форм ${ }^{42}$. В литературе описаны различные модификации тригидроксида алюминия $\mathrm{Al}(\mathrm{OH})_{3}$. Из них наиболее распространенными являются: гиббсит (гидраргиллит), байерит и нордстрандит. Моногидроксид алюминия $\mathrm{AlOOH}$ известен в виде двух модификаций: диаспор и бемит ${ }^{43}$. Кроме этих кристаллических фаз, в литературе встречаются сведения о ряде других гидроксидов алюминия. Однако эти формы недостаточно хорошо изучены. Поэтому остановимся на обсуждении кристаллического строения лишь гиббсита, байерита, нордстрандита, диаспора и бемита.

Нейтрализацию раствора алюмината натрия углекислым газом рекомендуют для получения чистых фаз гидроксида алюминия. Механизм этого процесса выражается следующей схемой ${ }^{44}$ :

${ }^{40}$ Bradley, S.M., Kydd, R.A., and Yamdagni, R. (2005) Study of the hydrolysis of combined $\mathrm{Al}^{3+}$ and $\mathrm{Ga}^{3+}$ aqueous solutions: formation of an extremely stable $\mathrm{GaO}_{4} \mathrm{Al}_{12}(\mathrm{OH})_{24}\left(\mathrm{H}_{2} \mathrm{O}\right)_{12}{ }^{7+}$ polyoxycation. Magn. Reson. Chem., 28, 746-750.

${ }^{41}$ Roswell J. and Nazar L. F. Speciation and Thermal Transformation in Alumina Sols: Structures of the Polyhydroxyoxoaluminum Cluster $\left[\mathrm{Al}_{30} \mathrm{O}_{8}(\mathrm{OH})_{56}\left(\mathrm{H}_{2} \mathrm{O}\right)_{26}\right]^{18+}$ and Its $\delta$-Keggin Moiete. J. Am. Chem. Soc., 2000, 122, 3777. https://doi.org/10.1021/ja993711.

${ }^{42} \mathrm{~K}$. Wade and A. J. Banister, in 'Comprehensive Inorganic Chemistry', ed. J.C. Bailar, Jr., H.J. Emelcus, R. Nyholm and A.F. Trotman-Dickenson, Pergamon, Oxford, 1972, vol. 1, p. 993.

43 Липпенс Б.К., Стеггерда И.И. Активная окись алюминия. - В кн.: Строение и свойства адсорбентов и катализаторов / Под ред. Б.Н. Линсена. Москва : Мир, 1973, с. 190-284.

44 Липпенс Б.К., Стеггерда И.И. Активная окись алюминия. В кн.: Строение и свойства адсорбентов и катализаторов / Под ред. Б.Н.Линсена. Москва : Мир, 1973 , с. $190-284$. 


$$
\begin{aligned}
& \text { Раствор алюмината натрия }+\mathrm{CO}_{2} \\
& \rightarrow \text { Аморфный гидроксид алюминия } \stackrel{20^{\circ} \mathrm{C}, p H<7}{\longrightarrow} \\
& \rightarrow \text { Гелеобразный Бемит } \stackrel{20^{\circ} \mathrm{C}, p H>9}{\longrightarrow} \text { Байерит } \stackrel{20^{\circ} \mathrm{C}, p H>12}{\longrightarrow}
\end{aligned}
$$

$\rightarrow$ Гиббсит $\stackrel{>80^{\circ} \mathrm{C}, p H>12}{\longrightarrow}$ Хорошо окристаллизованный Бемит

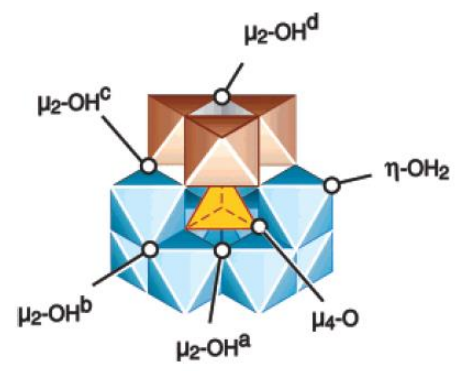

A)

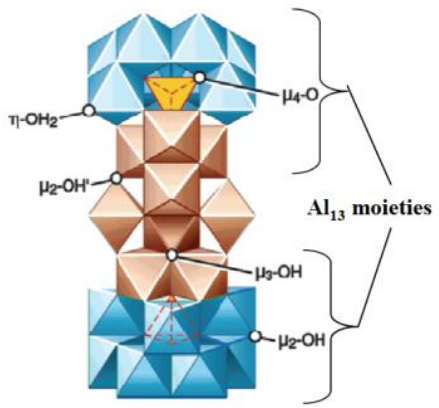

Б)

Рис. 4. А) Строение иона $\left.\mathrm{Al}_{13} \mathrm{O}_{4}(\mathrm{OH})_{24}\left(\mathrm{H}_{2} \mathrm{O}\right)_{12}\right]^{7+}$. На рисунке показано, как двенадиать октаэдров $A 1 O_{6}$ соединены вместе общими краями. Тетраэдр из атомов кислорода $\left(\mathrm{O}_{2}\right)$ в центре этой группы содержит атом алюминия с координированным числом $4^{45,46}$;

Б) Асимметричная структурная единица в полиэдральном виде, присутствующая в кристаллическом $\left[\mathrm{Al}_{30} \mathrm{O}_{8}(\mathrm{OH})_{56}\left(\mathrm{H}_{2} \mathrm{O}\right)_{26}\right]$ $\left[\mathrm{SO}_{4}\right]_{9} \times \mathrm{XH}_{2} \mathrm{O}\left(\mathrm{Al}_{30} \text { или « } \mathrm{Al}_{\mathrm{P} 2} »\right)^{4748}$

45 Kudryavtsev P. Application of Methods of Statistical Thermodynamics for Modeling Equilibrium in Polyfunctional Ion-Exchangers. Journal "Scientific IsraelTechnological Advantages", Vol.21, no.4, 2019, p. 49-74.

${ }^{46}$ Johansson, G. (1960) On the crystal structures of some basic aluminium salts. Acta Chem. Scand., 14, 771-773.

${ }^{47}$ Roswell J. and Nazar L. F. Speciation and Thermal Transformation in Alumina Sols: Structures of the Polyhydroxyoxoaluminum Cluster $\left[\mathrm{Al}_{30} \mathrm{O}_{8}(\mathrm{OH})_{56}\left(\mathrm{H}_{2} \mathrm{O}\right)_{26}\right]^{18+}$ and Its $\delta$-Keggin Moiete. J. Am. Chem. Soc., 2000, 122, 3777. https://doi.org/10.1021/ja993711.

${ }^{48}$ Casey W.H. Large Aqueous Aluminum Hydroxide Molecules. Chem. Rev. 2006, Vol. 106, №1, pp.1-16. https://doi.org/10.1021/cr040095d. 
Также установлено, что $\mathrm{AlO}(\mathrm{OH})$ может быть получен в виде бемита при добавлении аммиака к кипящему раствору соли алюминия или из суспензии гиббсита в воде в автоклаве при температуре $300^{\circ} \mathrm{C}{ }_{50,51}^{49}$.

В ряде работ ${ }^{50,51}$ было обнаружено, что природный и синтетический гиббсит всегда содержит ионы $\mathrm{Na}^{+}$в количестве $0,2 \div 0,3 \%$. Промывание кислотами не снижает количество натрия в твердой фазе. Хотя многие авторы утверждают, что без ионов щелочных металлов структура гиббсита вообще не может существовать, но этот эффект еще не доказан ${ }^{52}$.

В противоположность гиббситу, для байерита не возникает вопрос о возможности стабилизации его структуры ионами щелочных металлов. В кристаллическом бемите $\mathrm{AlO}(\mathrm{OH}),-A l-O-A l-O$ - цепи соединяются с атомами кислорода ОН-групп соседней цепи. По данным ${ }^{53}$ байерит имеет триклинную структуру. В результате такого искажения структуры получается, что минимальное расстояние $O-O$ между атомами кислорода в двух соседних слоях в байерите большие (313 nм), чем в гиббсите $(282 \mathrm{~nm})$.

Интересная закономерность, связывающая кислотно-основные свойства и структуру гидратированных оксидов в твердом состоянии, обнаружена Megaw H.D. ${ }^{54}$. При небольшом поляризующем влиянии катиона $\mathrm{OH}^{-}$- группы упаковываются как нейтральные группы, и между центрами атомов кислорода сохраняется большое расстояние. В другом предельном случае, при значительном поляризующем влиянии катиона, возникает сильное притяжение между $\mathrm{OH}^{-}$- группами, в результате чего они приближаются друг к другу. Ниже, в таблице 1, приведены расстояния между атомами кислорода, иллюстрирующие этот эффект ${ }^{55}$.

49 Sato, T. (1972), The thermal transformation of Gelatinous Aluminium Hydroxide. Z. anorg. allg. Chem., 391: 167-173. doi: 10.1002/zaac.19723910210.

50 Брэг У.Л., Кларингоулл Г.Ф. Структура минералов. Москва : Мир, 1967, c. 390.

51 Липпенс Б.К., Стеггерда И.И. Активная окись алюминия. В кн.: Строение и свойства адсорбентов и катализаторов / Под ред. Б.Н. Линсена. Москва : Мир, 1973 , с. $190-284$.

${ }_{52}^{52}$ См. сноску 51.

${ }_{53}^{53}$ См. сноску 51.

${ }^{54}$ Megaw H.D. Dia Untersuehung der Strucktur A1(OH $)_{3}$. Zeite. Krist., 1934. Bd.87. S. 185.

${ }^{55}$ См. сноску 54. 
Таблица 1

Сравнение расстояния между атомами кислорода (nм) в структурах различных гидратированных оксидах

\begin{tabular}{|c|c|c|c|c|c|}
\hline $\mathrm{LiOH}$ & 361 & $\mathrm{Ca}(\mathrm{OH})_{2}$ & 336 & $\mathrm{Mg}(\mathrm{OH})_{2}$ & 322 \\
\hline $\mathrm{Zn}(\mathrm{OH})_{2}$ & 283 & $\mathrm{Al}(\mathrm{OH})_{3}$ & 281 & $\mathrm{~B}(\mathrm{OH})_{3}$ & 265 \\
\hline
\end{tabular}

Длина связи $O-$ H...O в гидратированных оксидах, обладающих кислотными свойствами, составляет в среднем 265 nм. Таким образом, байерит должен сильнее проявлять основные свойства, чем гиббсит. Поэтому гидратированный оксид алюминия со структурой байерита будет легче подвергаться пептизации под действием кислот, а гиббсита - под действием щелочей.

Глинозем, $\mathrm{Al}_{2} \mathrm{O}_{3}$, получают путем дегидратации $\mathrm{AlO}(\mathrm{OH})$ или $\mathrm{Al}(\mathrm{OH})_{3}$ в, по меньшей мере шести типов, из которых $\alpha-\mathrm{Al}_{2} \mathrm{O}_{3}$ (корунд) является формой, образуемой только при высокой температуре. $\alpha-\mathrm{Al}_{2} \mathrm{O}_{3}$ является неограниченно метастабильной при обычных температурах ${ }^{56,57} . \mathrm{B} \alpha-\mathrm{Al}_{2} \mathrm{O}_{3}$, ионы кислорода образуют гексагональный плотноупакованный массив, в котором ионы $\mathrm{Al}^{3+}$ распределены симметрично среди октаэдрических позиций ${ }^{58}$. Кристаллы гиббсита дают листовую структуру, основанную на двойном слое плотноупакованных гидроксильных ионов, при этом $\mathrm{Al}^{3+}$ располагается в двух третях октаэдрических позиций ${ }^{59}$. Реже форму $\mathrm{Al}(\mathrm{OH})_{3}$, нордстрандит, получают путем регулирования кристаллизации гелеобразного гидроксида добавлением хелатообразующего агента, этиленгликоля.

Существуют различные формы смешанных оксидов, содержащие алюминий и различные металлы. В таких смешанных оксидах ионы второго металла могут замещать $\mathrm{Al}^{3+}$ в октаэдрических позициях, или

56 Brown P.L., Ekberg C. Hydrolysis of Metal Ions. Volume 1-2, Wiley-VCH, 2016, 945 p. ISBN: 978-3-527-65621-9

57 Petz J.I. Structure of Aluminum Hydroxide Gel, The Journal of Chemical Physics, 48, 909-911 (1968), DOI: http://dx.doi.org/10.1063/1.1668734.

58 Saalfeld H.L., Wedde M., Refinement of the crystal structure of gibbsite, $\mathrm{A} 1(\mathrm{OH})_{3}$, Zeitschrift für Kristallographie - Crystalline Materials. Volume 139, Issue 1-6, Pages 129-135, ISSN (Online) 2196-7105, ISSN (Print) 2194-4946, DOI: $10.1524 /$ zkri.1974.139.16.129.

59 Saalfeld H.L., Wedde M., Refinement of the crystal structure of gibbsite, $\mathrm{A} 1(\mathrm{OH})_{3}$, Zeitschrift für Kristallographie - Crystalline Materials. Volume 139, Issue 1-6, Pages 129-135, ISSN (Online) 2196-7105, ISSN (Print) 2194-4946, DOI: 10.1524/zkri.1974.139.16.129. 
занимать пустующие тетраэдрические позиции. Классическим примером такого смешанного оксида является шпинель $\mathrm{MgAl}_{2} \mathrm{O}_{4}$. Структура шпинели была исследована методами фотоэлектронной спектроскопии $^{60}$. Колебательные и методы ЯМР твердого состояние также являются полезными для изучения структуры алюминатных соединений ${ }^{61,62,63}$.

Самым простым смешанным оксидом алюминия, содержащим щелочные металлы, является алюминат натрия $\mathrm{NaA}_{10}$. Его получают нагреванием $\mathrm{A}_{2} \mathrm{O}_{3}$ с оксалатом натрия, карбонатом натрия или едким натром при $800 \div 1000{ }^{\circ} \mathrm{C}$. Алюминат натрия образует белые кристаллы ромбической сингонии, параметры ячейки $\boldsymbol{a}=537 n м, \boldsymbol{b}=521 n м, \boldsymbol{c}=707 n м, \boldsymbol{z}=4$. Известно еще несколько соединений типа алюмината натрия в системе $\mathrm{Na}_{2} \mathrm{O}-\mathrm{Al}_{2} \mathrm{O}_{3}$. Так $\mathrm{Na}_{5} \mathrm{~A}_{10} \mathrm{O}_{4}$ образует ромбическую структуру: она содержит дискретную цепь тетраэдров $\mathrm{A}_{10}$, в которых $\mathrm{R}_{\mathrm{Al}-\mathrm{O}}=176,1 \div 178,9$ nм. Триклинный алюминат натрия $\mathrm{Na}_{7} \mathrm{Al}_{3} \mathrm{O}_{8}$, содержит кольцевую структуру, полученную из шести тетраэдрических $\mathrm{A}_{10}$ групп, связанных кислородными мостиками в бесконечной цепи, в то время как $\mathrm{Na}_{17} \mathrm{Al}_{5} \mathrm{O}_{16}$ имеет дискретные цепи из пяти тетраэдров $\mathrm{A}_{10}$, распределенные по углам 64,65,66.

${ }^{60}$ Haycock D.E., Nicholls C.J., Urch D.S, Webber M.J., Wiech G. The electronic structure of magnesium dialuminium tetraoxide (spinel) using X-ray emission and X-ray photoelectron spectroscopies, J. Chem. Soc., Dalton Trans., 1978, 1785-1790, DOI: 10.1039/DT9780001785.

${ }^{61}$ Fraas, L.M., Moore, J.E., Salzberg, J.B. Raman characterization studies of synthetic and natural $\mathrm{MgAl}_{2} \mathrm{O}_{4}$ crystals, The Journal of Chemical Physics, Vol. 58, 3585-3592 (1973), DOI: http://dx.doi.org/10.1063/1.1679704.

${ }^{62}$ Saine M.C., Husson E., Brusset H., Cerez de A. Etude vibrationnelle d'aluminates et de gallates de terres rares-III. Aluminates et gallates de structure grenat, Spectrochimica Acta Part A: Molecular Spectroscopy, Vol. 38, № 1, 1982, pp. 25-29.

${ }^{63}$ Alemany L.B., Kirker G.W. 1.First observation of 5-coordinate aluminum by MAS aluminum-27 NMR in well-characterized solids, Journal of the American Chemical Society 1986108 (20), 6158-6162, DOI: 10.1021/ja00280a008.

${ }^{64}$ Leonard A.J., Van Cauwelaert P., Fripiat J.J. Structure and properties of amorphous silicoaluminas. III. Hydrated aluminas and transition aluminas. J.Phys.Chem. 1967. V. 71, № 3. P. 695-708.

65 Barker M.G., Gadd P.G. and Michael J. BegleyM.J., Identification and characterisation of three novel compounds in the sodium-aluminium-oxygen system, J. Chem. Soc., Dalton Trans., 1984, N 6, p. 1139-1146, doi:10.1039/DT9840001139.

${ }^{66}$ Kaduk J.A., Pei S., The Crystal Structure of Hydrated Sodium Aluminate, $\mathrm{NaAlO}_{2} \cdot 5 / 4 \mathrm{H}_{2} \mathrm{O}$, and Its Dehydration Product, Journal of Solid State Chemistry, Vol. 115, N 1, 1995, p. 126-139, doi:10.1006/jssc.1995.1111. 
ЯМР-спектроскопия атомов Al, применительно к поликристаллическим алюминатам, показывает характерные химические сдвиги для $\mathrm{A} 1 \mathrm{O}_{4}, \mathrm{~A}_{10}$ и $\mathrm{A}_{10}$ полиэдров ${ }^{67}$. Исследование алюмосиликатных растворов, осуществленное в работе ${ }^{68}$, показало, что технологические процессы также обеспечивают формирование связей $\mathrm{Si}-\mathrm{O}-\mathrm{Al}$, по $\mathrm{AlO}_{4}$ группам. В структуре $\mathrm{Cs}_{2} \mathrm{~A} 1_{2} \mathrm{O}(\mathrm{OH})_{6}$ анион состоит в двух тетраэдров $\mathrm{A}_{10}$, разделенных одним атомом кислорода ${ }^{69}$. Комплексные анионы $\left[\mathrm{Al}_{4}(\mathrm{OH})_{16}\right]^{4-}$ и $\left[\mathrm{AlO}(\mathrm{OH})^{2-}\right]_{\infty}$ составлены из тетраэдрических групп, распределенных равномерно, их структуры были определены по дифракции рентгеновских лучей при исследовании алюминатов бария ${ }^{70,71}$. Основной сульфат алюминия $\mathrm{Al}_{2}(\mathrm{OH})_{4}\left(\mathrm{SO}_{4}\right) \cdot 7 \mathrm{H}_{2} \mathrm{O}$ (алюминит) содержит комплексный катион $\left[\mathrm{Al}_{4}(\mathrm{OH})_{8}\left(\mathrm{OH}_{2}\right)_{6}\right]^{4+}$, построенный из четырех связанных ребрами октаэдров $\mathrm{A}_{10}$, которые образуют полимерные цепи. Эти цепи соединены между собой ионами $\mathrm{SO}_{4}{ }^{2-}{ }^{72}$. Октаэдрическая координация алюминия в алюминатах кальция, которые являются основными компонентами портландцемента, была идентифицирована методами рентгеновской кристаллографии ${ }^{73}$. В другой области прикладной химии алюминия спектры ЯМР в условиях вращения под магическим углом были использованы, чтобы проследить гидратацию и дегидратацию позиций A1 в ZSM-5

${ }^{67}$ Alemany L.B., Kirker G.W. 1.First observation of 5-coordinate aluminum by MAS aluminum-27 NMR in well-characterized solids, Journal of the American Chemical Society 1986108 (20), 6158-6162, DOI: 10.1021/ja00280a008.

${ }^{68}$ Muller D., D. Hoebbel D., Gessner W. ${ }^{27} \mathrm{Al}$ NMR studies of aluminosilicate solutions. Influences of the second coordination sphere on the shielding of aluminium Chemical Physics Letters, Volume 84, Issue 1, 15 November 1981, Pages 25-29, doi:10.1016/0009-2614(81)85362-6.

${ }^{69}$ Ivanov-Emin B.N., Kazier G.Z., Ivleva V.I., Aksenova T.B. Russ. J. Inorg. Chem. (Engl. Transl.), 1981, 26, 295.

${ }^{70}$ Glasser L.S.D., Giovanoli R. Barium aluminate hydrates. IV. The crystal structure of $\alpha-\mathrm{Ba}_{2}\left[\mathrm{Al}_{4}(\mathrm{OH})_{16}\right]$, Acta Cryst. (1972). B28, 519-524, [doi:10.1107/S0567740872002675].

${ }^{71}$ Glasser L.S.D., Giovanoli R. Barium aluminate hydrates. V. The crystal structure of $\gamma-\mathrm{Ba}\left[\mathrm{AlO}(\mathrm{OH})_{2}\right]_{2}$, Acta Cryst. (1972). B28, 760-763. doi:10.1107/S0567740872003152.

${ }^{72}$ Sabelli C., Ferroni R.T. The crystal structure of aluminite, Acta Cryst. (1978). B34, 2407-2412, [doi:10.1107/S0567740878008341].

${ }^{73}$ Vincent M.G., Jeffrey J.W. The crystal structure of pentacalcium trialuminate, $5 \mathrm{CaO} \cdot 3 \mathrm{Al}_{2} \mathrm{O}_{3}$, Acta Cryst. (1978). B34, $1422-1428$ [doi:10.1107/S0567740878005828]. 
цеолитах. В этих соединениях также была зафиксирована октаэдрическая координация алюминия ${ }^{74}$.

Гидратированный катион алюминия $\left[\mathrm{Al}\left(\mathrm{OH}_{2}\right)_{6}\right]^{3+}$ имеет октаэдрическую форму. Ниже представлены некоторые кристаллы, в которых он встречается (в скобках указано среднее расстояние A1-O): $\quad \mathrm{NaAl}\left(\mathrm{SO}_{4}\right)_{2} \cdot \mathrm{H}_{2} \mathrm{O} \quad(187,8 \quad n м) ;$ Меллайт (Mellite), также называемый «Медовый камень», представляющий собой соль алюминия из меллитовой кислоты, с химической формулой $\mathrm{Al}_{2} \mathrm{C}_{6}(\mathrm{COO})_{6} \cdot 16 \mathrm{H}_{2} \mathrm{O}^{75}(187,2 \mathrm{~nm}) ; \mathrm{A} 1 \mathrm{CuC} 1\left(\mathrm{SO}_{4}\right)_{2} \cdot 14 \mathrm{H}_{2} \mathrm{O}(187,8 \mathrm{~nm})^{76}$. Эти кристаллы были также исследованы методом нейтронной дифракции и методами ЯМР ${ }^{1} \mathrm{H}$, которые подтверждают наличие $\left[\mathrm{Al}\left(\mathrm{OH}_{2}\right)_{6}\right]^{3+}$ и разрешают локализацию атомов водорода молекул воды, находящихся в координационной сфере ${ }^{77}$. По данным комбинационного рассеяния колебательные режимы иона $\left[\mathrm{Al}\left(\mathrm{OH}_{2}\right)_{6}\right]^{3+}$ в кристаллах различных квасцов были определены следующим образом $v_{1}=542, v_{2}=473, v_{5}=347 \mathrm{~cm}^{-1} 78$. В спектрах комбинационного рассеяния монокристаллов соли $\left[\mathrm{Al}\left(\mathrm{OH}_{2}\right)_{6} \mathrm{Cl}_{3}\right.$ имеет место колебательная мода $v_{\text {сим }}(\mathrm{Al}-\mathrm{O})$ на частоте $524 \mathrm{~cm}^{-1} 79$. Алюминил-катионы $\mathrm{A} \mathrm{O}^{+}$изолированные от $\mathrm{HF}$ растворов, в виде $\mathrm{BF}^{4-}$ или $\mathrm{SbF}^{6-}$ солей, показывают v(Al-O) вблизи $650 \mathrm{~cm}^{-1} 80$.

${ }^{74}$ Kentgens A.P.M., Scholle K.F.M.G.J., Veeman W.S.. Effect of hydration on the local symmetry around aluminum in ZSM-5 zeolites studied by aluminum-27 nuclear magnetic resonance, J. Phys. Chem., 1983, 87 (22), pp 4357-4360, DOI: $10.1021 / \mathrm{j} 100245 \mathrm{a} 008$.

${ }^{75}$ Пенкось Р. Алкоголяты алюминия. Успехи химии. 1968, т. 37, № 4, с. 647-676.

${ }^{76}$ Ginderow, D. and Cesbron, F. (1979), Structure cristalline de l'aubertite, $\mathrm{AlCuCl}\left(\mathrm{SO}_{4}\right)_{2} \cdot 14 \mathrm{H}_{2} \mathrm{O}$. Acta Cryst. B, Vol. 35, pp. 2499-2502. doi: 10.1107/S0567740879009766.

${ }^{77}$ Hermansson, K. (1983), A neutron diffraction determination of the structure of deuterated aluminium nitrate nonahydrate, $\mathrm{A} 1\left(\mathrm{NO}_{3}\right)_{3} \cdot 9 \mathrm{D}_{2} \mathrm{O}$. Acta Crystallographica C, Vol 39: pp. 925-930. doi: 10.1107/S0108270183006897.

${ }^{78}$ Best S.P., Armstrong R.S., Beattie J.K. Vibrational spectroscopic studies of trivalent hexa-aqua-cations: single-crystal Raman spectra of caesium aluminium alums between 300 and $1200 \mathrm{~cm}^{-1}$, J. Chem. Soc., Dalton Trans., 1982, 1655-1664, DOI: 10.1039/DT9820001655.

79 Adams D.M., Hills D.J. Single-crystal Raman and infrared study of aluminium trichloride hexa-hydrate, J. Chem. Soc., Dalton Trans., 1978, 782-788, DOI: 10.1039/DT9780000782.

${ }^{80}$ Pankratov A.V., Skachkov A.N., Shalaeva O.N., Kurbatov G.M. Russ. J. Inorg. Chem. (Engl. Transl.), 1972, 17, 47. 
Полосы комбинационного рассеяния, очень концентрированных растворов $\mathrm{A} 1\left(\mathrm{NO}_{3}\right)_{3}$, согласуются с $\left[\mathrm{Al}\left(\mathrm{OH}_{2}\right)_{6}\right]^{3+}$ и $\mathrm{NO}_{3}^{-}$в форме разделенных растворителем ионных пар ${ }^{81}$. Протоны гидратной оболочки и массы воды можно различать с помощью ЯМР ${ }^{1} \mathrm{H}$. Сигналы ЯМР ${ }^{27} \mathrm{~A} 1$ позволяют отличить ионы $\left[\mathrm{Al}\left(\mathrm{OH}_{2}\right)_{6}\right]^{3+}$ от других видов, таких как $\left[\mathrm{A} 1\left(\mathrm{OH}_{2}\right)_{5}\left(\mathrm{SO}_{4}\right)\right]^{+}$в сульфатных растворах или $\left[\mathrm{Al}_{2}(\mathrm{OH})_{2}\left(\mathrm{OH}_{2}\right)_{8}\right]^{4+}$ и более высоко полимеризованных комплексов, которые образуются при старении водных растворов алюминатов ${ }^{82}$. Согласно данным комбинационного рассеяния ${ }^{83}$ и данным ЯМР $84,85,86,87,88,89,90$ для катиона $\left[\mathrm{A}_{13} \mathrm{O}_{4}(\mathrm{OH})_{25}\left(\mathrm{OH}_{2}\right)_{11}\right]$, который образует

${ }^{81}$ Kriutsov N.V., Shirokova G.N., Rosolovskii V.Ya. Russ. J. Inorg. Chem. (Engl. Trans1.), 1973, 18, 503.

82 Teagarden, D.L., Radavich, J.F., White, J.L., Hem, S.L. Aluminum chlorohydrate II: Physicochemical properties, J. Pharm. Sci., 1981, Vol. 70, 7, 762-764, DOI: 10.1002/jps.2600700712.

${ }^{83}$ Waters D.N., Henty M.S. Raman spectra of aqueous solutions of hydrolysed aluminium(III) salts, J. Chem. Soc., Dalton Trans., 1977, 243-245, DOI: $10.1039 / \mathrm{DT} 9770000243$.

${ }^{84}$ Ohman L.-O., Forsling W., Equilibrium and Structural Studies of Silicon(IV) and Aluminium(III) in Aqueous Solution. 3. Potentiometric Study of Aluminium(III) Hydrolysis and Aluminium(III) Hydroxo Carbonates in $0.6 \mathrm{M} \mathrm{Na}(\mathrm{Cl})$. Acta Chem. Scand, Ser. A, 1981, Vol. 35, pp. 795-802.

${ }^{85}$ Müller D., Gessner W., Schönherr S., Görz H., Über basische Aluminiumsalze und ihre Lösungen. X. NMR-Untersuchungen am tridekameren Al-oxo-hydroxoKation, Z. anorg. allg. Chem., 1981, Vol. 483, 12, pp. 153-160, DOI: $10.1002 /$ zaac. 19814831219.

86 Schönherr, S., Görz, H., Müller, D., Gessner, W. Über basische Aluminiumsalze und ihre Lösungen. VI. Darstellung und Charakterisierung eines wasserlöslichen Al13O40-Chlorides, Z. anorg. allg. Chem., 1981, Vol. 476, 5, pp. 188-194, DOI: 10.1002/zaac.19814760522.

${ }^{87}$ Schönherr, S., Görz, H., Gessner, W., Winzer, M., Müller, D. Über basische Aluminiumsalze und ihre Lösungen. VII. Zum Einfluß der Herstellungsbedingungen, der Konzentration und der Alterungszeit auf die Zusammensetzung von Lösungen basischer Aluminiumsalze, Z. anorg. allg. Chem. 1981, Vol. 476, 5, 195-200, DOI, 10.1002/zaac.19814760523.

88 Schönherr, S., Görz, H. Darstellung und Eigenschaften von Heteropolykationenverbindungen. I. Über das Dodekaaluminogermaniumsulfat $\left[\mathrm{GeO}_{4} \mathrm{Al}_{12}(\mathrm{OH})_{24}\left(\mathrm{H}_{2} \mathrm{O}\right)_{12}\right]\left(\mathrm{SO}_{4}\right)_{4} \cdot x \mathrm{H}_{2} \mathrm{O}$, Z. anorg. allg. Chem., 1983, Vol. 503, 8, pp. 37-42, DOI: 10.1002/zaac.19835030805.

${ }^{89}$ Lampe, F., Müller, D., Gessner, W., Grimmer, A.-R., Scheler, G. Über basische Aluminiumsalze und ihre Lösungen. XI. Vergleichende ${ }^{27}$ Al-NMRUntersuchungen am Mineral Zunyit und basischen Aluminium-Salzen mit tridekameren Al-oxo-hydroxo-aquo-Kationen, Z. anorg. allg. Chem., 1982, Vol. 489, 1, pp. 16-22, DOI: 10.1002/zaac.19824890104. 
растворимые сульфат и хлорид, и сохраняется в водном растворе 91,92,93,94. В присутствии НC1 он разлагается на более мелкие частицы, но при добавлении щелочей могут быть сформированы частицы с более высокой молекулярной массой. В сильнощелочных растворах соединений алюминия преобладающими разновидностями являются моноядерные ионы $\left[\mathrm{Al}\left(\mathrm{H}_{2} \mathrm{O}\right)_{2}(\mathrm{OH})_{4}\right]^{-},\left[\mathrm{Al}(\mathrm{OH})_{6}\right]^{-}$и биядерные ионы $\left[\mathrm{A}_{2} \mathrm{O}(\mathrm{OH})_{6}\right]^{2-95,96,97,98}$.

УФ-спектры водных растворов $\mathrm{A} 1 \mathrm{C} 1_{3}, \mathrm{~A} 1\left(\mathrm{ClO}_{4}\right)_{3}, \mathrm{~A} 1\left(\mathrm{NO}_{3}\right)_{3}$ и $\mathrm{A}_{2}\left(\mathrm{SO}_{4}\right)_{3}$ также подтверждают преобладание в их структуре катиона гекса-аква-алюминия. Присутствие полосы поглощения при $240 \mathrm{Hм}$ обусловлено переносом заряда между внутренней координационной сферой и растворителем:

$$
\left[\mathrm{Al}\left(\mathrm{H}_{2} \mathrm{O}\right)_{6}\right]^{3+} \leftrightarrow\left[\mathrm{Al}(\mathrm{OH})\left(\mathrm{H}_{2} \mathrm{O}\right)_{5}\right]^{2+}+\mathrm{H}^{+}
$$

${ }^{90}$ Schönherr, S., Görz, H., Bertram, R., Müller, D., Gessner, W. Über basische Aluminiumsalze und ihre Lösungen. (XII). Vergleichende Untersuchungen an unterschiedlich dargestellten Basischen Aluminiumchloridlösungen, Z. anorg. allg. Chem., 1983, Vol. 502, 7, pp. 113-122, DOI: 10.1002/zaac.19835020715.

91 Brand, P., Seltmann, U. Über basische Aluminiumsalze und ihre Lösungen. (XIII). Kristalline basische Aluminiumchloride als Produkte der Rehydratisierung und Hydrochlorierung von Übergangstonerden, Z. anorg. allg. Chem., 1983, Vol. 502, 7, pp. 123-131, DOI: 10.1002/zaac.19835020716.

92 Brand, P., Seltmann, U., Müller, D., Büchner, U. Über basische Aluminiumsalze und ihre Lösungen. XIV. Zur Strukturellen Funktion des Wassers in basischen Aluminiumchloriden, Z. anorg. allg. Chem., 1983, Vol. 502, 7, 132-140, DOI: $10.1002 /$ zaac.19835020717.

${ }^{93}$ Schönherr, S., Bertram, R., Görz, H. Über basische Aluminiumsalze und ihre Lösungen. XVI. Kinetische Untersuchungen an niederbasischen Aluminiumchloridlösungen, Z. anorg. allg. Chem., 1983, Vol. 503, 8, pp. 193-200, DOI: $10.1002 /$ zaac. 19835030820 .

94 Kühling, M., Röbisch, G., Kinetische Untersuchungen zum Abbau von $\mathrm{Al}_{13} \mathrm{O}_{40}$-Kationen durch Salzsäure, Z. anorg. allg. Chem., 1991, Vol. 603, 1, pp. 137-143, DOI: 10.1002/zaac.19916030118.

95 Mesmer R.E., Baes C.F., Jr. Acidity measurements at elevated temperatures. V. Aluminum ion hydrolysis, Inorg. Chem., 1971, 10 (10), pp 2290-2296, DOI: 10.1021/ic50104a040.

${ }^{96}$ Moolenaar R.J., Evans J.C., McKeever L.D. J. Phys. Chem. 1.Structure of the aluminate ion in solutions at high $\mathrm{pH}$, The Journal of Physical Chemistry 1970 74 (20), 3629-3636, DOI: 10.1021/j100714a014.

97 Szabó, Z. G., Wajand, J., Ruff, I. and Burger, K. (1978), Investigation of Aluminate Solutions by water activity measurement. Z. anorg. allg. Chem., 441: 245-251. doi: 10.1002/zaac.19784410128.

98 Akitt J.W., GessnerW. Aluminium-27 nuclear magnetic resonance investigations of highly alkaline aluminate solutions, J. Chem. Soc., Dalton Trans., 1984, pp. 147-148, DOI: 10.1039/DT9840000147. 
Также было обнаружено, что хлоридные и перхлорат-анионы не замещают внутрисферные аква-группы в ионах гекса-акваалюминия. При этом сульфат-анион, входя во внутреннюю координационную сферу, вызывал уменьшение этой линии, вплоть до полного еe исчезновения. Измерения эквивалентной проводимости показали, что сульфатный анион при концентрациях выше 0,50 М демонстрирует более сильное ионное спаривание, чем хлорид, нитрат и перхлорат. Этот эффект подтвердил вывод о том, что сульфат-анион может входить во внутреннюю координационную сферу $\mathrm{Al}^{3+99}$.

Для выяснения стереохимических ограничений, связанных со структурами гидратов алюминия, были проведены расчеты значения энергий с помощью метода молекулярных орбиталей, для комплексных ионов состава $\left[\mathrm{Al}\left(\mathrm{OH}_{2}\right)_{\mathrm{n}}\right]^{3+} \quad(\mathrm{n}=1 \div 7) \quad 100$, и гидроксокомплексов $\left[\mathrm{Al}(\mathrm{OH})_{4}\right]^{-},\left(\mathrm{Al}(\mathrm{OH})_{5}\right)^{2-}$ или $\left(\mathrm{Al}_{2}(\mathrm{OH})_{8}\right)^{2-}{ }^{101}$. Были выполнены расчеты для молекул $\mathrm{H}_{3} \mathrm{~A} 1 \mathrm{OH}_{2}$ и $\left(\mathrm{H}_{2} \mathrm{~A} 1 \mathrm{OH}\right)_{2}$ с помощью метода молекулярных орбиталей также 102 . Подтверждения возможности существования подобных молекул не было получено. Однако малые молекулы такого рода иногда могут быть обнаружены с использованием методов матричной изоляции. Например, при взаимодействии атомов алюминия с молекулами $\mathrm{H}_{2} \mathrm{O}$ в экстремальных условиях, происходит образование соединение типа $\mathrm{HAlOH}$, в то время как более тяжелые металлы III группы образуют $\mathrm{M} \cdot \mathrm{OH}_{2}$ аддукты ${ }^{103}$.

Существует несколько различных модификаций гидратированного оксида алюминия. Наиболее широко используемой формой является псевдобемит. Псевдобемит является одной из самых

${ }^{99}$ McIntyre J.F., Foley R.T., Brown B.F. Ultraviolet spectra of aluminum salt solutions, Inorg. Chem., 1982, 21 (3), pp. 1167-1172, DOI: 10.1021/ic00133a056.

${ }^{100}$ Veillard H. Hydration of the cation's aluminum $(3+)$ and copper. A theoretical study, J. Am. Chem. Soc., 1977, 99 (22), pp 7194-7199, DOI: 10.1021/ja00464a016.

101 Hill R.J., Gibbs G.V., Peterson R.C., A Molecular Orbital Study of the Stereochemistry of Pentacoordinated Aluminium, Aust. J. Chem. 1979, Vol. 32, pp. 231-241. http://dx.doi.org/10.1071/CH9790231.

${ }^{102}$ Gropen O., Johansen R., Haaland A., Stokkeland O. Ab initio molecular orbital calculations on $\mathrm{H}_{3} \mathrm{AlOH}_{2},\left(\mathrm{H}_{2} \mathrm{AlOH}\right)_{2}$, and some related species, Journal of Organometallic Chemistry, Vol. 92, 2, 1975, Pages 147-156, http://dx.doi.org/10. 1016/S0022-328X(00)92083-7.

${ }^{103}$ Hange R.H., Kaufman J.W., Margrave J.L. Infrared matrix-isolation studies of the interactions and reactions of Group 3A metal atoms with water, J. Am. Chem. Soc., 1980, Vol. 102, 19, 6005-6011. 
подвижных форм гидратированных оксидов алюминия, с точки зрения ее взаимодействия с кислотами и щелочами. Основным способом получения псевдобемита на действующих производствах является переосаждение гидроксида алюминия, которое заключается в растворении гидраргиллита в кислоте или щелочи с последующей нейтрализацией и выделением осадка - гидратированного геля (гидрогеля). Полученный гидратированный гель, в определенных условиях старения при $\mathrm{pH} \quad 7,5 \div 9,0$ и температуре $20 \div 70 \quad{ }^{\circ} \mathrm{C}$ превращается в псевдобемит ${ }^{104}$. Процесс старения гидрогеля, состоит в постепенном обезвоживании. При этом происходят образование мостиковых связей через гидроксо-группы с участием свободных электронных пар кислорода. Эти процессы называются оляцией, а образующиеся группы называются оловыми группами $-O_{\ldots .}^{H}$. Реакцию образования оловых соединений из гидроксо- или аквакомплексов иногда называют оляцией, а процесс получения оксосоединений из гидроксо-, аква- или оловых соединений - оксоляцией $^{105}$. Образованию оловых соединений (оляция) и превращению их в оксосоединения (оксоляция) способствуют повышение температуры и концентрации раствора, а также его длительное выдерживание. Обратные процессы превращения оловых соединений в мономерные ионы протекает очень медленно, при этом превращение оксогрупп в оловые почти невозможно ${ }^{106}$.

Процессы оксоляции с образованием мостиковых оксо-связей или оксо-групп происходят параллельно. Процесс старения завершается последующей за ним кристаллизацией, с изменением строения молекул по следующей схеме:

Гидратированные катионы алюминия

$$
\begin{aligned}
& \left(\left[\mathrm{Al}\left(\mathrm{H}_{2} \mathrm{O}\right)_{6}\right]^{3+}\right. \text {; } \\
& \mathrm{Al}(\mathrm{OH})\left(\mathrm{H}_{2} \mathrm{O}\right)_{5}^{2+} \text {; } \\
& \mathrm{Al}(\mathrm{OH})_{2}\left(\mathrm{H}_{2} \mathrm{O}\right)_{4}^{+} \text {; } \\
& \mathrm{Al}_{2}(\mathrm{OH})_{2}\left(\mathrm{H}_{2} \mathrm{O}\right)_{8}^{4+} \text {; } \\
& \rightarrow \begin{array}{c}
\text { Свежеосажденны } \\
\text { й аморфный гель } \\
\left(\left[\mathrm{Al}_{4} \mathrm{O}_{2}(\mathrm{OH})_{8}\right]_{n}\right)
\end{array} \rightarrow \quad \begin{array}{c}
\text { Псевдобемит } \\
{\left[\mathrm{Al}_{4} \mathrm{O}_{3}(\mathrm{OH})_{6}\right]_{n}}
\end{array} \\
& \text { Псевдобемит } \\
& \mathrm{Al}_{13}(\mathrm{OH})_{24}\left(\mathrm{H}_{2} \mathrm{O}\right)_{12}^{7+}
\end{aligned}
$$

104 Дзисько В.А., Карнаухов А.П., Тарасова Д.В. Физико-химические основы синтеза окисных катализаторов. Новосибирск: Наука, 1978. 384 с.

105 Желиговская Н.Н., Черняев И.И. Химия комплексных соединений. Москва : Мир, 1979. 568 с.

106 Химия и технология редких и рассеянных элементов, ч. II. Под ред. К.А. Большакова, Изд.2-е, Москва : Высшая Школа, 1976. 360 с. 
При этом происходит изменение формы частиц:

Мицеллы
золя $\rightarrow \begin{gathered}\text { Аморфные } \\ \text { образования из частиц } \\ \text { золя }\end{gathered} \rightarrow \begin{gathered}\text { Волокна (иголки) или } \\ \text { кристаллы размером }\end{gathered}$

Скорость перехода каждой ступени определяется величиной $\mathrm{pH}$ среды, температурой и временем ${ }^{107}$. Образование псевдобемита идет путем кристаллизации в объеме аморфных сферических частиц, основу которых составляют моно- и биядерные гидроксокомплексы алюминия, с последующим формированием волокон или иголок по механизму «ориентированного наращивания» $^{108}$. Причем для начала кристаллизации достаточно, чтобы произошла дегидратация $20 \div 40 \%$ аморфного гидроксида, чем и объясняется фазовая неоднородность псевдобемита.

При старении доля гидроксосолей уменьшается, а содержание структурной воды снижается до $1,5 \div 1,7$ моля $\mathrm{H}_{2} \mathrm{O}$ /моль $\mathrm{Al}_{2} \mathrm{O}_{3}$. Наличие в псевдобемите смеси двух и более морфологических форм (волокнистого аморфного, тонкодисперсного, игольчатого) значительно усложняет, а иногда и искажает результаты по изучению формирования пористой структуры активного оксида алюминия.

Работа ${ }^{109}$ посвящена теоретическому исследованию химии явлений сольватации солей алюминия. В ней обсуждены такие фундаментальные аспекты, как структурные характеристики комплексных ионов алюминия, гидролиз, кислотность, структура сольватов, влияние противоионов и химическая стабильность. Статические расчеты, дополненные моделью экранирования, использовались для исследования целого ряда возможных плоских и циклических конфигураций двуядерных, трехядерных, тетраядерных и пентаядерных алюминиевых комплексов. Проведены расчеты молекулярной динамики для исследований их поведения в водных средах. Проведен структурный анализ продуктов гидролиза

107 Дзисько В.А., Карнаухов А.П., Тарасова Д.В. Физико-химические основы синтеза окисных катализаторов. Новосибирск : Наука, 1978. 384 с.

108 Криворучко О.П., Буянов Р.А. Развитие теории кристаллизации малорастворимых гидроксидов и ее применение в научных основах приготовления катализаторов. Всесоюзная школа по катализаторам / ИК СО АН. Новосибирск, 1982. С. 122-150.

109 Saukkoriipi, Jaakko, Theoretical study of the hydrolysis of aluminum complexes. Faculty of Science, Department of Chemistry, University of Oulu, Acta Univ. Oul. A 554, 2010, 90 p. 
$\mathrm{AlCl}_{3} \cdot 6 \mathrm{H}_{2} \mathrm{O}$. Двуядерные, триядерные и тетраядерные гидроксо-хлоркомплексы алюминия были исследованы как в газовой, так и в жидкой фазах. Изучена химия сульфатных комплексов алюминия. Выявлены продукты гидролиза $\mathrm{AlCl}_{3} \cdot 6 \mathrm{H}_{2} \mathrm{O}$ в присутствии сульфатов. Также изучены структурные характеристики продуктов гидролиза $\mathrm{Al}_{2}\left(\mathrm{SO}_{4}\right)_{3} \cdot 18 \mathrm{H}_{2} \mathrm{O}$. Дополнительная структурная информация была получена из результатов масспектроскопии и с помощью вычислительных методов. Обнаруженные катионные структуры оказались аналогичными, образующимся при гидролизе хлор-гидрата алюминия. Изучен гидролиз, стабильность и динамика двуядерных и пентаядерных гидроксо-хлор-комплексов алюминия в водных средах. При моделировании было обнаружено несколько спонтанных ассоциативных реакций гидратации в первичной гидратной оболочке комплексов. Было обнаружено, что двуядерные хлоргидраты алюминия стабильны в жидких условиях, тогда как пентаядерные комплексы алюминия претерпевали значительные топологические изменения. Проведенные автором расчеты позволили объяснить некоторые аномалии, обнаруженные в экспериментах.

Проведенный нами анализ позволил разработать методы синтеза неорганических ионообменных материалов на основе гидратированных оксидов алюминия, обладающих преимущественно анионообменными свойствами.

\section{2. Экспериментальная часть}

\section{1. Методы синтеза и исследования ионообменных свойств материалов}

Осаждение образцов гидратированного оксида алюминия проводили при фиксированных значениях рН. Было реализовано два варианта осуществления реакции взаимодействия реагентов: прямой и обратный порядок сливания реагентов. Прямой порядок сливания растворов предусматривал добавлением $0,1 \mathrm{M}$ раствора $\mathrm{NaOH}$ к 0,1 M раствору сульфата алюминия. Обратный порядок сливания растворов предусматривал приливание $0,1 \mathrm{M}$ раствора $\mathrm{H}_{2} \mathrm{SO}_{4} \quad$ к $\quad 0,1 \quad \mathrm{M}$ раствору $\mathrm{Na}\left[\mathrm{Al}(\mathrm{OH})_{4}\right]$. Полученные осадки промывали водой и гранулировали с использованием метода высушиванием на воздухе при комнатной температуре с последующей декрипитацией. Образцы с добавками различных ионов готовили следующим образом. Добавки ионов вольфрама $\mathrm{W}(\mathrm{VI})$ вводили в раствор алюмината натрия или $\mathrm{NaOH}$ в виде соли 
$\mathrm{NaWO}_{4}$. Добавки ионов $\mathrm{Ti}(\mathrm{IV})$ и $\mathrm{Zr}(\mathrm{IV})$ вводили в растворы $\mathrm{AlCl}_{3} \cdot 6 \mathrm{H}_{2} \mathrm{O}$ или $\mathrm{Al}_{2}\left(\mathrm{SO}_{4}\right)_{3} \cdot 18 \mathrm{H}_{2} \mathrm{O}$ в соответственно в виде их сульфатов или хлоридов. Дальнейшее осаждение смешанных гидроксидов осуществляли добавлением раствора $\mathrm{NaOH}$. Для получения сорбентов использовались свежеприготовленные растворы соответствующих солей. Во всех экспериментах при синтезе сорбентов, постоянное значение $\mathrm{pH}$ поддерживалось с помощью системы автоматического регулирования расхода реагентов на базе автоматического титратора. Для гранулирования сорбентов на основе смешанных гидроксидов также был применен метод высушивания с последующей декрипитацией. Декрипитация представляет собой разрушение больших частиц ксерогеля после его замачивания в воде за счет капиллярных сил. Для получения моноионных форм сорбентов их обрабатывали $0,1 \mathrm{H}$ раствором $\mathrm{NaOH}$, а затем водой, для удаления ионов $\mathrm{Na}^{+}$.

Ионообменные свойства синтезированных материалов изучали как в статических, так и в динамических условиях. Исследование ионообменных свойств материалов в статических условиях проводилось с использованием герметичных сосудов, которые помещались во вращающейся кассете (60 об/мин) для перемешивания. Перемешивание осуществлялось до установления равновесия между твердой и жидкой фазами. В динамических условиях использовали методики, обычные для колоночного метода. Во всех экспериментах при исследовании ионообменных свойств синтезированных материалов применяла специальные меры, предотвращающие поглощение растворами $\mathrm{CO}_{2}$ из воздуха.

Кислотно-основные свойства синтезированных материалов исследовали методом потенциометрического титрования с использованием $0,1 \mathrm{M}$ растворов $\mathrm{HC} 1$ или $\mathrm{NaOH}$ при стабилизации ионной силы растворов $(I=0,1$, корректировка $\mathrm{NaCl}$. Расчет констант диссоциации обменных центров проводили по методике, описанной в работе ${ }^{110}$. Для расчетов констант диссоциации было использовано уравнение кривой титрования, которая имела следующий вид:

$$
E_{M e^{+}}=\sum_{i=1}^{N} \frac{E_{i}}{\left(1+\frac{a_{H^{+}}}{a_{M e^{+}} K_{i}}\right)}
$$

${ }^{110}$ Kudryavtsev P. Application of Methods of Statistical Thermodynamics for Modeling Equilibrium in Polyfunctional Ion-Exchangers. Journal "Scientific IsraelTechnological Advantages". Vol. 21, no. 4, 2019, p. 49-74. 
Это выражение описывает ионообменник с дискретным набором обменных центров. Как отмечалось в работе ${ }^{111}$, уравнения (2) обладают свойством зарядовой симметрии. Оно справедливы как для протонодонорных, так и для протоноакцепторных центров. Для протоноакцепторных центров уравнение изотермы сорбции аналогично. В связи с этим уравнение (2) можно применять как для случаев катионного обмена, так и для анионообменников. Для расчетов использовался метод минимизации функционала среднеквадратичной невязки ${ }^{112}$. Функционал среднеквадратичной невязки представляет собой функцию, имеющую несколько локальных экстремумов. Для этой системы мы использовали алгоритм покоординатного сканирования функционала на заданном числе точек с выбором лучшей точки для последовательности значений.

\section{2. Методика исследования структуры аморфных материалов по диффузному рассеянию рентгеновских лучей}

Изучение строения полученных образцов гидратированного оксида алюминия проводили методом диффузного рассеяния рентгеновских лучей ${ }^{113}$. Исследование диффузного рассеяния рентгеновских лучей на аморфных образцах проводилось методом отражения от образца, на рентгеновском дифрактометре ДРОН-4-07 с использованием $\mathrm{CuK}_{\alpha}, \mathrm{CoK}_{\alpha}, \mathrm{FeK}_{\alpha}$ - излучения с монохроматором на первичном пучке. Флуоресцентное излучение отфильтровывалось амплитудным дифференциальным дискриминатором. Величина некогерентного рассеяния вычислялась теоретически по формуле ${ }^{114,115}$ :

$$
\begin{gathered}
I_{\mathrm{HK}}(s)=\frac{1}{B^{3}}\left[Z^{2}-\sum_{j} f_{j}(s)\right] \\
B=1+\frac{2 h \lambda}{m c}\left(\frac{\sin \Theta}{\lambda}\right)
\end{gathered}
$$

${ }^{111}$ См. сноску 111.

112 См. сноску 111.

113 Скрышевский А.Ф. Структурный анализ жидкостей и аморфных тел. Москва : Высшая школа, 1980.

114 Татаринова Л.И. Электронография аморфных тел. Москва : Наука, 1972. $102 \mathrm{c}$.

${ }^{115}$ См. сноску 114. 


$$
s=\frac{4 \pi \sin \Theta}{\lambda}
$$

где $\Theta$ - угод рассеяния, $\lambda$ - длина волны рентгеновского излучения; $Z$ атомный номер элемента; $f_{j}(s)$ - фактор атомного рассеяния $\boldsymbol{j}$-атома.

Съемка кривых интенсивности производилась через $1^{\circ}$ в области $\Theta=5 \div 60^{\circ}$. Нормировка кривых интенсивности производилась с использованием коэффициента нормировки (К), вычисляемого по формуле ${ }^{116 .}$

$$
K=\frac{\int_{0}^{\infty} s^{2}\left[f_{k}^{2}(s)+I_{\mathrm{HК}}(s)\right] d s}{\int_{0}^{\infty} s^{2} I_{\text {экс }}(s) d s}
$$

После нормировки кривых интенсивности и вычета интенсивности некогерентного рассеяния проводилось вычисление кривой радиального распределения атомной плотности $G$ по уравнению ${ }^{117}$ :

$$
G=4 \pi R^{2} \sum_{j} \rho_{j}(R)=4 \pi R^{2} \rho_{\text {сп }}+\frac{2 R}{\pi} \int_{0}^{\infty} s[a(s)-1] \sin s R d s
$$

где $\rho_{j}(R)$ атомная плотность к мпонента $\boldsymbol{j}, \rho_{\text {сп }}-$ средняя атомная плотность, $a(s)$ - нормировочная кривая интенсивности, $R$ - межатомное расстояние.

\section{3. Результаты и обсуждение}

Амфотерные свойства гидратированного оксида алюминия ограничивают интервал $\mathrm{pH}$ его осаждения величинами примерно $5,0-9,5^{118}$. Экспериментально установлено, что полная обменная емкость (ПОЕ) гидратированного оксида алюминия по $\mathrm{Cl}^{-}$-иону в этом интервале слабо зависит от величины $\mathrm{pH}$ осаждения $\left(\mathrm{pH}_{\mathrm{oc}}\right)$ : для разных образцов ее значения находятся в пределах 1,6-2,1 моль/кг.

Можно предположить, что при осаждении из раствора алюмината, где алюминий находится преимущественно в виде ионов $\left[\mathrm{Al}\left(\mathrm{H}_{2} \mathrm{O}\right)_{2}(\mathrm{OH})_{4}\right]^{-119}$, возможно образование сорбента, содержащего

${ }^{116}$ См. сноску 114.

117 Скрышевский А.Ф. Структурный анализ жидкостей и аморфных тел. Москва : Высшая школа, 1980.

118 Лурье Ю.Ю. Справочник по аналитической химии. Москва : Химия, 1965.

${ }^{119}$ Bradley, S.M., Kydd, R.A., and Yamdagni, R. (2005) Study of the hydrolysis of combined $\mathrm{Al}^{3+}$ and $\mathrm{Ga}^{3+}$ aqueous solutions: formation of an extremely stable $\mathrm{GaO}_{4} \mathrm{Al}_{12}(\mathrm{OH})_{24}\left(\mathrm{H}_{2} \mathrm{O}\right)_{12}{ }^{7+}$ polyoxycation. Magn. Reson. Chem., 28, 746-750. 
некоторое количество алюминия с координационным числом 4. При осаждении же из раствора $\mathrm{Al}_{2}\left(\mathrm{SO}_{4}\right)_{3}$, где алюминий находится в состоянии с к.ч. $=6^{120,121,122}$, образуется сорбент, содержащий ионы $\mathrm{Al}^{3+}$ в октаэдрической конфигурации, эта ситуация соответствует фактам, изложенным в работе 123 . Исходя из классификации неорганических кислот по Риччи ${ }^{124,125}$, можно сделать вывод о том, что алюминий, проявляющий к.ч. $=4$, должен давать кислоты с менышей величиной $\mathrm{pK}_{\mathrm{a}}$ в отличие от алюминия с к.ч.=6.

Поскольку синтезируемые материалы представляют собой аморфные вещества, для исследования их строения применялся метод диффузного рассеяния рентгеновских лучей. Исследование диффузного рассеяния рентгеновских лучей этими образцами указывает на близость их структурного мотива. Результаты проведенных структурных исследований представлены на рисунке 5.

Однако анализ полученных структурных данных не позволяет сделать вывод о наличии в фазе гидратированного оксида алюминия значительных количеств ионов $\mathrm{A}^{3+}$ с координационным числом 4, так как на всех кривых радиального распределения атомной плотности заселенность первой координационной сферы равна примерно 6. Кроме того, существенных различий на этих зависимостях для образцов, полученных в различных условиях, не наблюдается.

${ }^{120}$ Brand, P., Seltmann, U. Über basische Aluminiumsalze und ihre Lösungen. (XIII). Kristalline basische Aluminiumchloride als Produkte der Rehydratisierung und Hydrochlorierung von Übergangstonerden, Z. anorg. allg. Chem., 1983, Vol. 502, 7, pp. 123-131, DOI: 10.1002/zaac.19835020716.

${ }^{121}$ Johansson, G. (1960) On the crystal structures of some basic aluminium salts. Acta Chem. Scand., 14, 771-773.

122 Bradley, S.M., Kydd, R.A., and Yamdagni, R. (2005) Study of the hydrolysis of combined $\mathrm{Al}^{3+}$ and $\mathrm{Ga}^{3+}$ aqueous solutions: formation of an extremely stable $\mathrm{GaO}_{4} \mathrm{Al}_{12}(\mathrm{OH})_{24}\left(\mathrm{H}_{2} \mathrm{O}\right)_{12}{ }^{7+}$ polyoxycation. Magn. Reson. Chem., 28, 746-750.

${ }^{123}$ Schönherr, S., Bertram, R., Görz, H. Über basische Aluminiumsalze und ihre Lösungen. XVI. Kinetische Untersuchungen an niederbasischen Aluminiumchloridlösungen, Z. anorg. allg. Chem., 1983, Vol. 503, 8, pp. 193-200, DOI: $10.1002 /$ zaac. 19835030820 .

124 Онорин С.А., Вольхин В.В., Ходяшев М.Б., Сесюнина Е.А., Алпатова Е.В. Свойства композиционных титансодержащих сорбентов. Межвузовский сборник научных трудов: Химия и технология неорганических сорбентов. Пермь : 1989, с. 124-129.

125 Дей К., Селбин Д. Теоретическая неорганическая химия. Москва : Мир, 1969. 432 с. 
На основе кривых радиального распределения атомной плотности была предпринята попытка определения структуры гидратированного оксида алюминия, образующейся при осаждении, методом моделирования его структурного мотива.

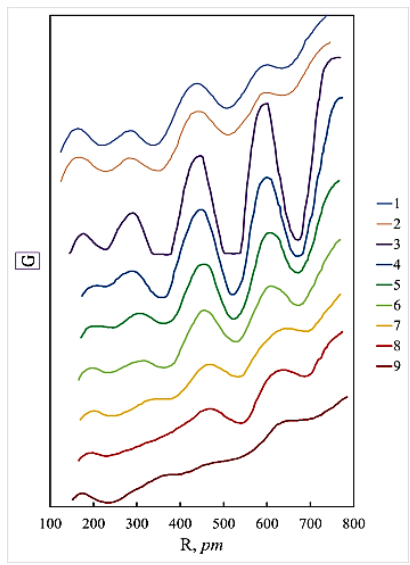

Рис. 5. Кривые радиального распределения атомной плотности в образцах гидратированного оксида алюминия, полученных при $\mathrm{pH}=7,8(1,2), 9,0$ (3-9) и содержащих добавки ионов Ti(IV) (в ат. \%): 0 (1) - «обратный» метод сливания растворов, 0 $(2,3)$ - здесь и далее «прямой» метод сливания растворов, $4,8(4), 9,1(5), 14,3(6), 25,0(7), 33,3(8), 100$ (9)

Нами был использован принцип сравнения межатомных расстояний в известных структурах и полученных из кривых радиального распределения атомной плотности. При этом обнаружено, что в синтезированных материалах полученные межатомные расстояния совпадают с межатомными расстояниями, полученными для гиббсита ${ }^{126,127}$. Соответственно, параметры гипотетической кристаллической решетки синтезированного гидратированного оксида алюминия, рассчитанные из кривых

${ }^{126}$ Megaw H.D. Dia Untersuehung der Strucktur A1(OH $)_{3}$. Zeite. Krist., 1934. Bd.87. S. 185.

127 Липпенес Б.К., Стеггерда И.И. Активная окись алюминия. В сб.: Строение и свойства адсорбентов и катализаторов. Москва : МИР, 1973, c. $190-284$. 
радиального распределения и выбранного мотива упаковки атомов, оказались близки к параметрам элементарных ячеек решеток структуры гиббсита ${ }^{128}$ (таблица 2).

Кристаллические структуры гиббсита, байерита и нордстрандита схожи между собой и базируются на двойном слое гидроксильных ионов, упакованных приблизительно плотнейшим образом. Атомы алюминия находится в октаэдрической координации, занимая, однако, лишь $2 / 3$ возможных позиций ${ }^{129}$. Строение кристаллической решетки гиббсита $\mathrm{Al}(\mathrm{OH})_{3}$ представлено на рисунке 6 .

Слои удерживаются вместе водородными связями, возникающими между ионами $\mathrm{OH}^{-}$. При этом каждая гидроксильная группа одного слоя располагается против $\mathrm{OH}^{-}-$ группы следующего слоя. В результате получается моноклинная структура со следующими параметрами решетки $\boldsymbol{a}=862,4 \mathrm{nM}$, $\boldsymbol{b}=506,0$ nм, $\boldsymbol{c}=972,0$ nм, $\boldsymbol{\beta}=94^{\circ} 34^{\prime}, \boldsymbol{z}=8^{130}$.

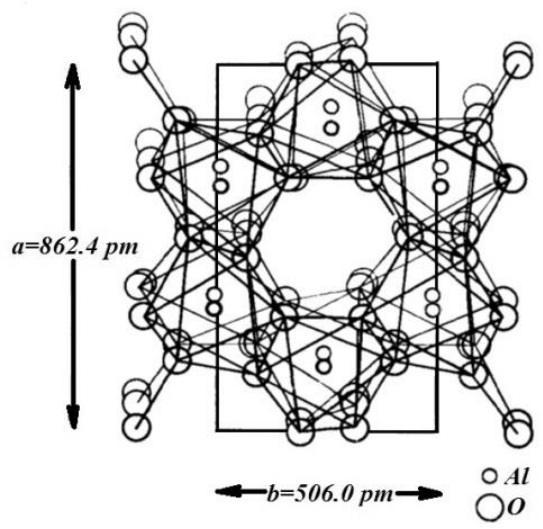

Рис. 6. Структура гиббсита $\mathrm{Al}(\mathrm{OH})_{3}$. $a$ и $b$ - параметры элементарной ячейки

Вычисленные из кривых радиального распределения атомной плотности (КРРАП) расстояния ОН ••ОН составляют 300-340 pm,

${ }^{128}$ См. сноску 127.

${ }^{129}$ См. сноску 127.

130 Брэг У.Л., Кларингоулл Г.Ф. Структура минералов. Москва : Мир, 1967, c. 390. 
а заселенность первой координационной сферы алюминия близка к 6. Эти величины, а также значения межплоскостных расстояний для материалов, определенные по кривым радиального распределения атомной плотности, наилучшим образом соответствуют гиббситу ${ }^{131}$. Расчет параметров элементарной ячейки образцов гидратированного оксида алюминия по модели с характерной для гиббсита упаковкой атомов в решетке показывает, что синтезированные материалы имеют более аморфизированную структуру, чем у индивидуального гиббсита (табл. 2).

Таблица 2

Параметры элементарных ячеек решеток гиббсита и образцов гидратированный оксида алюминия, полученных при рН=9,0

\begin{tabular}{|c|c|c|c|c|c|c|}
\hline Материал & $\begin{array}{c}\text { Пространственная } \\
\text { группа }\end{array}$ & $\boldsymbol{z}$ & $\begin{array}{c}\boldsymbol{a}, \\
\boldsymbol{p m}\end{array}$ & $\begin{array}{c}\boldsymbol{b}, \\
\boldsymbol{p m}\end{array}$ & $\begin{array}{c}\boldsymbol{c}, \\
\boldsymbol{p m}\end{array}$ & $\boldsymbol{\beta}$ \\
\hline Гиббсит ${ }^{132}$ & $\mathrm{P} 2_{1} / \mathrm{n}$ & 8 & 868 & 507 & 972 & $94,5^{\circ}$ \\
\hline ГОА, $\mathrm{pH} \mathrm{oc}_{\mathrm{oc}}=9,1$ & $\mathrm{P} 2_{1} / \mathrm{n}$ & 8 & 887 & 567 & 911 & $\sim 90^{\circ}$ \\
\hline ГОА, $\mathrm{pH}_{\mathrm{oc}}=7,8$ & $\mathrm{P} 2_{1} / \mathrm{n}$ & 8 & 922 & 606 & 1001 & $\sim 90^{\circ}$ \\
\hline $\begin{array}{c}\text { ГОА+9, } 1 \text { ат. } \% \\
\text { Ті(IV) }\end{array}$ & $\mathrm{P} 2_{1} / \mathrm{n}$ & 8 & 908 & 581 & 986 & $\sim 90^{\circ}$ \\
\hline $\begin{array}{c}\text { ГОА+20,0 ат. \% } \\
\text { Тi(IV) }\end{array}$ & $\mathrm{P} 2_{1} / \mathrm{n}$ & 8 & 915 & 588 & 1002 & $\sim 90^{\circ}$ \\
\hline
\end{tabular}

Приведенные данные еще раз подтверждают предположение о максимальном разрыхлении структуры гидратированный оксида алюминия при получении его в области рН близких к 8.

Изменение порядка сливания растворов при осаждении гидратированного оксида алюминия оказывает слабое влияние на строение образующихся продуктов. Значения $\mathrm{pK}$ их обменных ОН-групп и величину полной обменной емкости (рисунок 7). Кривые потенциометрического титрования образцов гидратированного оксида алюминия, полученных при $\mathrm{pH}_{\mathrm{oc}}=7,8$ «прямым» и «обратным» методами, показывают на наличие у них преимущественно основной функции: величина полной обменной емкости полученных осадков по ионам $\mathrm{Cl}^{-}$и $\mathrm{Na}^{+}$составляет

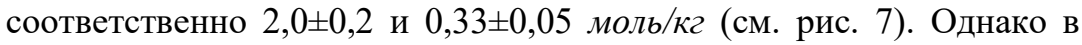

131 Брэг У.Л., Кларингоулл Г.Ф. Структура минералов. Москва : Мир, 1967, c. 390.

132 Брэг У.Л., Кларингоулл Г.Ф. Структура минералов. Москва : Мир, 1967. c. 390. 
образце гидратированного оксида алюминия, полученным «прямым» методом, возрастает доля более основных ОН-групп с $\mathrm{pK}_{b 1}=5.97 \pm 0.04$ и $\mathrm{pK}_{b 1}=5.14 \pm 0.06$. Кроме того, несколько снижается кислотность ОН-групп, участвующих в обмене катионов $\mathrm{pK}_{a}=9.75 \pm 0.08$ и $\mathrm{pK}_{a}=9.30 \pm 0.07$ соответственно. По этой причине величина анионообменной емкости образца достигает $0,5-0,8$ моль C1-/кг уже в растворах с реакцией среды, близкой к нейтральной.

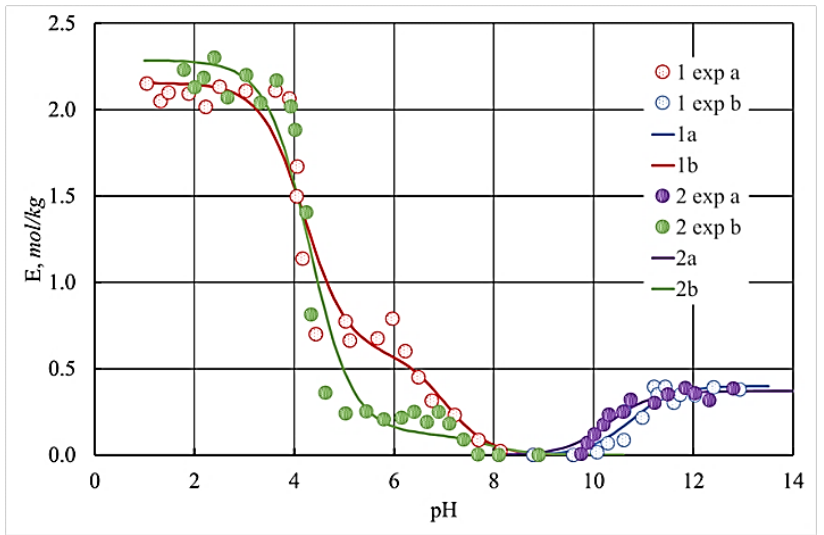

Рис. 7. Кривые потенциометрического титрования образцов гидратированного оксида алюминия, полученных при «прямом» (1) и «обратном» (2) порядке сливания растворов. 1 exp b и 2 exp b - экспериментальные данные для анионообменной части кривой;

2 exp а и 2 exp а - экспериментальные данные для катионообменной части кривой; $1 \mathrm{~b}$ и $2 \mathrm{~b}$ - расчетные данные для анионообменной части кривой; 1а и $2 \mathrm{a}$ - расчетные данные для катионообменной части кривой

Рассчитанные значения констант кислотной (a) и основной (b) диссоииации: $1-p K_{a}=9.75 \pm 0.08 ; 2-p K_{a}=9.30 \pm 0.07 ; 1-p K_{b 1}=$ $5.97 \pm 0.04 ; p K_{b 2}=8.79 \pm 0.06 ; 2-p K_{b 1}=5.14 \pm 0.06 ; p K_{b 2}=8.69 \pm 0.07$; Соответствующие им значения ионообменной емкости материала: $1-E_{a}=0.40 \pm 0.01 ; 2-E_{a}=0.37 \pm 0.01 ; 1-E_{b 1}=0.59 \pm 0.02 ; E_{b 2}=1.56 \pm 0.04$; $2-E_{b 1}=0.123 \pm 0.008 ; E_{b 2}=2.16 \pm 0.06$. Индексы 1 и 2 относятся $\kappa$ соответствующим типам ионообменных иентров

Одна из причин различия кислотно-основных свойств синтезированных материалов заключается в различной плотности 
упаковки атомов в твердой фазе. Как отмечалось в работах ${ }^{133,134}$, расстояние О-Н...О в гидратированных оксидах, обладающих кислотными свойствами, составляет $2,55 \AA$ в щелочных - от 3,3 до $3,6 \AA$ (см. Таблицу 1). В кристаллическом гидроксиде алюминия это расстояние составляет $2,79 \AA{ }^{135}$. Расстояние О-Н...О в синтезированных нами материалах составляет $3,0 \pm 0,2 \AA$ для гидратированного оксида алюминия, полученного при $\mathrm{pH}=9,1$, и $3,2 \pm 0,3 \AA-$ при $\mathrm{pH}=7,8$. Из этих данных следует, что аморфный гидратированный оксид алюминия должна проявлять более основные свойства, чем кристаллический. Сравнение величин $\mathrm{pK}_{a}$ диссоциации ОН-групп кристаллической $\mathrm{Al}(\mathrm{OH})_{3}-\mathrm{pK}_{a}=8.86{ }^{136}$ и ГОА, полученной при $\mathrm{pH}=7.8-\mathrm{pK}_{a}=9.75 \pm 0.08$, подтверждает правильность сделанного предположения.

При исследовании влияния $\mathrm{pH}$ осаждения на анионообменные свойства гидратированный оксид алюминия было обнаружено, что эта зависимость имеет максимум (рисунок 8). Это явление, как показали структурные исследования (Рисунок 5), связано с различной упорядоченностью структуры гидратированного оксида алюминия, возникающей при осаждении из растворов с различным $\mathrm{pH}$. Максимум обменной емкости соответствует минимальной продолжительности зоны ближнего порядка.

Отмеченное явление может быть также связано с различным ходом процесса осаждения гидратированного оксида алюминия при изменении порядка сливания растворов. При гидролизе кислых растворов солей алюминия («прямой» метод синтеза гидратированного оксида алюминия) происходит образование поликатионных форм алюминия ${ }^{137138}$, а при гидролизе растворов алюминатов щелочных металлов - полианионных ${ }^{139}$.

${ }^{133}$ Megaw H.D. Dia Untersuehung der Strucktur A1(OH)3. Zeite. Krist., 1934. Bd.87. S. 185.

134 Вайнштейн Б.К., Фридкин В.М., Инденбом Р.Л. Современная кристаллография. 2 том. Структура кристаллов. Москва : Наука, 1979. 359 с.

135 См. сноску 133.

136 Рабинович Р.А., Хавин 3.Я. Краткий химический справочник. Ленинград : Химия, 1977. 376 с.

${ }^{137}$ Van Cauwelaert, F.H., Bosmans, H.J. Polycations formed in the hydrolysis of the aluminum ion. J. Rev. Chim. Minerale, 1969, Vol.6, No 3, p. 611-623.

138 Fripiat J.J., Van Cauwelaert F.H., Bosnians H.I. Structure of aluminum cations in agueous solutions // J. Phys. Chem. 1965. Vol. 69, N. 7. P. 2458-2461.

${ }^{139}$. Schofield, R.K., \& Taylor, A.W. The hydrolysis of aluminium salt solutions. Journal of the Chemical Society (Resumed), 1954, p. 4445-4448. doi:10.1039/jr9540004445. 


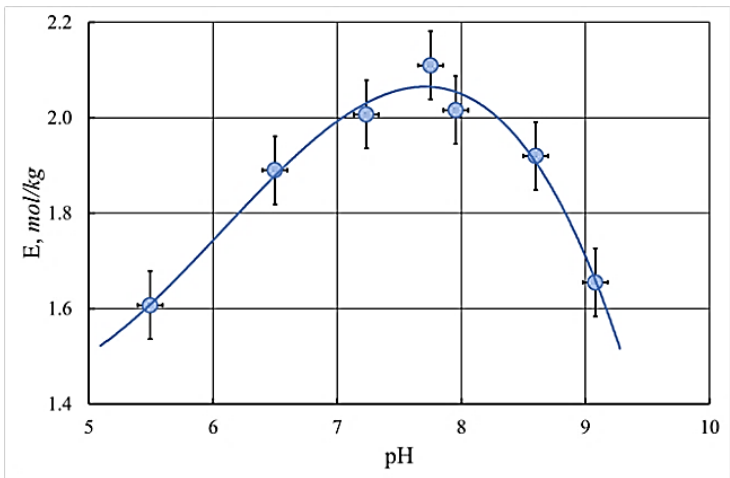

Рис. 8. Влияние рН осаждения гидратированного оксида алюминия на его анионообменную емкость по ионам $\mathrm{Cl}^{-}$

Условия «прямого» метода синтеза гидратированного оксида алюминия способствуют вхождению в состав осадка дополнительного количества присутствующих в растворе анионов, что, вероятно, и усиливает анионообменную функцию гидратированного оксида алюминия, но существенно не изменяет его структурный мотив.

Проведенные эксперименты показывают, что более целесообразным является применение гидратированного оксида алюминия в качестве анионообменника. Для его синтеза предпочтительнее использовать «прямой» порядок сливания растворов, обеспечивая $\mathrm{pH}_{\mathrm{oc}}=8,5 \pm 0,5$. Дополнительно следует обратить внимание на то, что увеличение $\mathrm{pH}$ осаждения приводит к росту ближнего порядка - кривые 2 и 3 на Рисунке 5. Сравнивая эти данные с составом жидкой фазы растворов солей алюминия в зависимости от $\mathrm{pH}$ (рисунок 1), можно заключить, что при осаждении из более щелочных сред при осаждении гидратированного оксида алюминия происходит образование преимущественно полианионных форм. Можно предположить, что они более склонны к упорядочению при осаждении. Кроме того, ранее отмечалось, что присутствие в твердой фазе ионов натрия способствует стабилизации фазы гиббсита ${ }^{140,141}$. Однако эти

140 Брэг У.Л., Кларингоулл Г.Ф. Структура минералов. Москва : Мир, 1967. c. 390.

141 Липпенс Б.К., Стеггерда И.И. Активная окись алюминия. В кн.: Строение и свойства адсорбентов и катализаторов / Под ред. Б.Н. Линсена. Москва : Мир, 1973, с. 190-284. 
эффекты почти не оказывают влияния на ионообменные свойства синтезированных образцов гидратированного оксида алюминия.

Более сильное влияние на ионообменные свойства гидратированного оксида алюминия оказывает введение в его состав легирующих ионов. Ионы $\mathrm{Ti}(\mathrm{IV}), \mathrm{Zr}(\mathrm{IV})$ и $\mathrm{W}(\mathrm{VI})$ были выбраны в качестве легирующих после анализа их кристаллохимических свойств ${ }^{142,143}$. Их введение в состав гидратированного оксида алюминия осуществляли на стадии его осаждения добавлением соответствующих солей в раствор хлорида алюминия ( $\left.\mathrm{TiCl}_{4}, \mathrm{ZrOCl}_{2}\right)$ или в раствор $\mathrm{NaOH}\left(\mathrm{Na}_{2} \mathrm{WO}_{4}\right)$. Использовался «прямой» метод сливания растворов, $\mathrm{pH}_{\mathrm{oc}}=8,5 \pm 0,5$. Гранулирование осадков проводили сушкой их на воздухе при комнатной температуре.

Влияние добавок ионов на строение гидратированного оксида алюминия рассмотрим на примере ионов $\mathrm{Ti}^{4+}$, так как последние привели к максимальному эффекту в плане увеличения обменной емкости. При анализе кривых радиального распределения атомной плотности в этих материалах (рисунок 5) обращает на себя внимание тенденция роста беспорядка в структуре, с увеличением количества добавки. Кривые, отражающие зависимость полной обменной емкости гидратированного оксида алюминия по Cl-иону (сорбтив - 0,1 M HCl) от содержания в нем легирующей добавки, имеют экстремальный характер (рисунок 9).

Для каждой добавки существует оптимальная область концентраций, в которой материал имеет максимальную величину полной обменной емкости, что может быть использовано для улучшения сорбционных свойств гидратированного оксида алюминия. Наилучшие результаты достигаются при легировании гидратированного оксида алюминия ионами $\mathrm{Ti}(\mathrm{IV})$. По этой причине данные материалы были исследованы более подробно.

Для оценки влияния добавки ионов Ti(IV) на кислотно-основные свойства синтезируемых материалов были изучены кривые потенциометрического титрования синтезированных образцов гидратированного оксида алюминия, содержащего 20 ат. \% Ti(IV). Анализ полученных данных указал на увеличение содержания в

142 Пятенко Ю.А., Воронков А.А., Пудовкина З.В. Минералогическая кристаллохимия титана. Москва : Наука. 1976. 155 с.

${ }^{143}$ Kudryavtsev P. Dissociation Constants of Hydrated Oxides of chemical elements in the D.I. Mendeleev Periodic System. Journal "Scientific IsraelTechnological Advantages", Vol. 21, no.5-6, 2019, p. 38-81. 
этом образце обменных ОН-групп по сравнению с исходным гидратированного оксида алюминия (рисунок 10). Присутствие в составе осадка ионов Ti(IV), имеющего более высокую электроотрицательность, чем Al(III), вероятно, является причиной некоторого увеличения значений их $\mathrm{pK}_{b 1}=7.30 \pm 0.02$, $\mathrm{pK}_{b 2}=9.25 \pm 0.01$, по сравнению с аналогичными значениями для гидратированного оксида алюминия - $\mathrm{pK}_{b 1}=5.97 \pm 0.04$; $\mathrm{pK}_{b 2}=8.79 \pm 0.06$. Однако в растворах с $\mathrm{pH}<6$ анионообменная емкость легированного образца остается в 2-4 раза выше, чем исходного гидратированного оксида алюминия, что делает его более перспективным для практического применения. Следует особо обратить внимание на то, что в данном случае модель ионообменника с дискретным набором обменных центров не совсем корректно описывает экспериментально полученные кривые потенциометрического титрования.

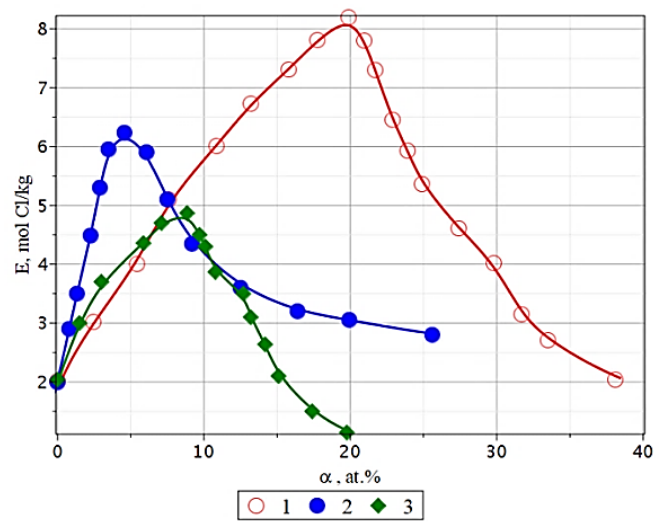

Рис. 9. Зависимость полной обменной емкости (Е, моль $\mathrm{Cl} /$ /к2) гидратированного оксида алюминия от содержания легирующих добавок Ti(IV) (1), Zr(IV) (2) и W(VI) (3)

в составе твердой фазы сорбента

$\alpha$-кониентращия легирующих ионов, ат.\%.

Из рисунка 10 видно, что расчетная кривая и экспериментальные точки в некоторых участках довольно сильно отклоняются друг от друга. Также в точке максимального перегиба экспериментальная зависимость имеет более крутой наклон, чем расчетная. Как 
отмечалось в работе ${ }^{144}$, уширение функции распределения обменных центров по константе обмена приводит только к уменьшению наклона кривой титрования в точке максимального перегиба. Полученное отклонение можно объяснить только эффектом воздействия сорбированных ионов на соседние обменные центры за счет индукционного эффекта, возникающего в следствие значительной делокализации электронов и образования $(\boldsymbol{p} \rightarrow \boldsymbol{d})_{\pi}$ сопряжений ${ }^{145}$. Как известно, делокализация электронов приводит к значительным индукционным эффектам ${ }^{146}$ и увеличению радиуса действия примесных центров ${ }^{147}$, в качестве которых с полным основанием можно считать ионы, поглощенные сорбентом в результате процесса ионного обмена.

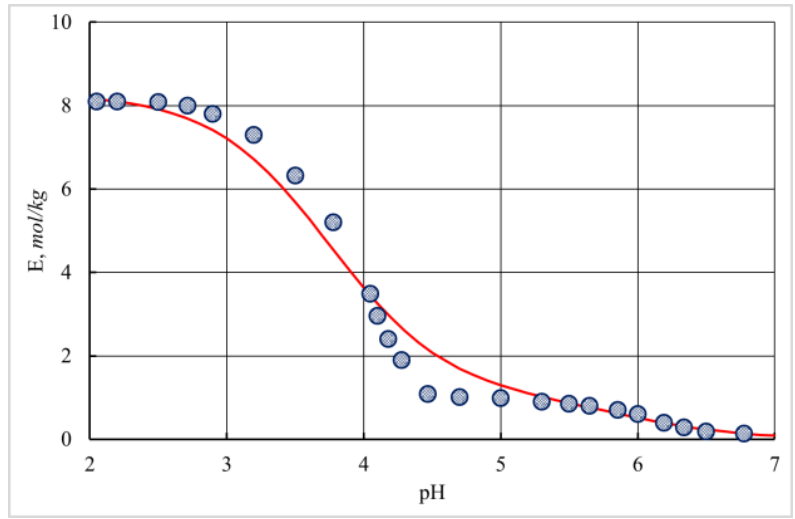

Рис. 10. Кривая потенциометрического титрования образца гидратированного оксида алюминия с добавкой 20 ат. \% Ti(IV). $\mathrm{pK}_{b 1}=7.30 \pm 0.02, \mathrm{pK}_{b 2}=9.25 \pm 0.01$

144 Kudryavtsev P. Application of Methods of Statistical Thermodynamics for Modeling Equilibrium in Polyfunctional Ion-Exchangers. Journal "Scientific IsraelTechnological Advantages". Vol.21, no.4. 2019. p. 49-74

${ }^{145}$ Нефедов В.Н. Взаимное влияние лигандов в соединениях переходных и непереходных элементов. В сб.: Трансвлияние в химии координационных соединений. Серия «Проблемы координационной химии». Москва : Наука. 1979. c. 73.

146 Маррел Дж., Кеттс С., Теддер Дж. Химическая связь. Москва : МИР. $1980.382 \mathrm{c}$.

147 Шальве О., Додель Р., Дине С., Мальрьё Ж.-П. Локализация и делокализация в квантовой химии. Атомы и молекулы в основном состоянии. Москва : МИР. 1978. 414 с. 
Не связывающие не поделённые пары обладают большими энергиями (им соответствуют большие диагональные элементы оператора Фока), особенно если они представляют собой чистые $\boldsymbol{\pi}$-орбитали, при этом растет энергия переноса заряда на валентные разрыхляющие молекулярные орбитали. В этом случае коэффициент для переноса заряда становится большим по величине, что приводит к значительным «хвостам» самосогласованных молекулярных орбиталей не поделенных пар на разрыхляющих вицинальных молекулярные орбитали, то есть на любые парные функциональные группы или атомы, прикрепленные к двум смежными атомам. «Хвосты» молекулярных орбиталей таких молекул имеют очень большие веса и приводят к связям, включающим три или четыре атома. В связи с этим эффектом можно ожидать изменения кислотно-основных свойств активных обменных центров гидратированных оксидов при введении в их структуру тяжелых ионов сорбтива. В данном случае можно предположить, что вхождение аниона сорбтива в структуру гидратированного оксида алюминия приводит к повышению основности соседних с сорбированным ионом обменных ОН-групп, и, соответственно, к увеличению крутизны кривой потенциометрического титрования по сравнению с ее классическим видом.

Изучение строения легированных ионами Ti(IV) образцов гидратированного оксида алюминия показывает, что увеличение в гидратированном оксиде алюминия содержания легирующих ионов приводит к уменьшению ближнего порядка (см рисунок 5) и к росту величины параметров его элементарной ячейки (см. таблицу 2). Особенно чувствительным к изменению концентрации добавки является параметр «с», который связан с расстоянием между слоями в структуре гиббсита ${ }^{148}$. Как видно из рисунка 5 и таблицы 2 , разупорядочение структуры материалов сопровождается увеличением межслоевых расстояний. Введение в состав гидратированного оксида алюминия более $25 \div 30$ ат. \% ионов Ti(IV) вообще приводит к изменению его структурного мотива.

Эти зависимости во всех исследованных образцах похожи друг на друга, и наблюдается лишь некоторое смещение положения максимумов. Следовательно, значительных структурных изменений при варьировании их состава не происходит. Поэтому можно на основе

148 Брэг У.Л., Кларингоулл Г.Ф. Структура минералов. Москва : Мир. 1967. c. 390 . 
предложенной модели структуры гидратированного оксида алюминия рассчитывать параметры элементарной ячейки используя кривые радиального распределения атомной плотности в соответствующих образцах. Вычисленные параметры представлены на рисунке 11 для добавок ионов $\mathrm{Ti}^{4+}$ в структуру гидратированного оксида алюминия.

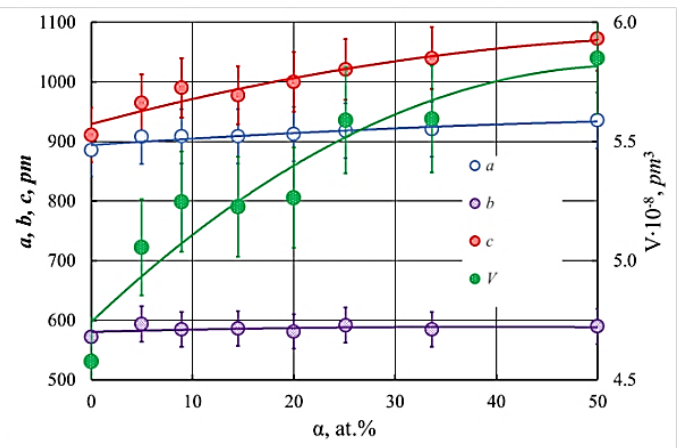

Рис. 11. Параметры элементарной моноклинной ячейки гидратированного оксида алюминия а (1), b (2), с (3), V (4), рассчитанные на основе кривых радиального распределения атомной плотности и предложенной структуры модели в зависимости от количества добавки ионов $\mathrm{Ti}^{4+}(\alpha$, ат.\%)

Полученные данные указывают на рост параметров элементарной ячейки с ростом количества добавки ионов $\mathrm{Ti}^{4+}$, что обычно наблюдается при образовании твердых растворов ${ }^{149}$. Особенно чувствителен к изменению количества добавки параметр “c” (Таблица 2). Обнаруженный эффект указывает на рост расстояния между слоями в образующихся материалах, что должно приводить к увеличению доступности сорбционных центров для обменных ионов. При введении добавок $\mathrm{Ti}^{4+}$, кроме увеличения доступности сорбционных центров, может проявляться тенденция увеличения их количества за счет нарушения баланса заряда в матрице сорбента. На основе полученных данных можно сделать вывод, что добавки ионов $\mathrm{Ti}^{4+}$ к гидратированному оксиду алюминия приводят, во-первых, к росту беспорядка, а во-вторых, к увеличению межслоевых расстояний в структуре синтезируемых материалов.

Полученные результаты позволяют предложить следующий механизм действия легирующих добавок, который объясняет ход

149 Ормонт Б.Ф. Введшие в физическую химию и кристаллохимию полупроводников. Изд. 2-е. Москва : Высшая школа. 1973. 655 с. 
кривых на рисунке 5. При изоморфном замещении части ионов $\mathrm{Al}(\mathrm{III})$ в структуре гидратированного оксида алюминия более высоко валентными ионами у матрицы возникает избыточный положительный заряд, который компенсируется появлением дополнительного количества ОН-групп, способных к участию в ионном обмене. Повышение концентрации легирующих ионов увеличивает содержание ОН-групп и величину полной обменной емкости гидратированного оксида алюминия, но ослабляет связь между слоями в его структуре. На определенном этапе происходит разрушение характерного для гидратированного оксида алюминия мотива структуры и, следовательно, изменение связанных с ним ионообменных свойств материала. Действие этих факторов приводит к появлению дополнительных экстремумов на кривых, изображенных на рисунке 9.

Другой проблемой, возникающей при изучении процессов анионного обмена на оксигидратных сорбентам, является выяснение характера взаимодействия сорбируемых анионов с оксигидратной матрицей. $\mathrm{C}$ этой целью были проведены эксперименты по сорбции анионов кислот различной силы (рисунок 12). Сорбцию вели на фоне $0,1 \mathrm{H}_{2} \mathrm{SO}_{4}$, концентрацию сорбируемого аниона поддерживали на уровне $0,01 \mathrm{M}$.

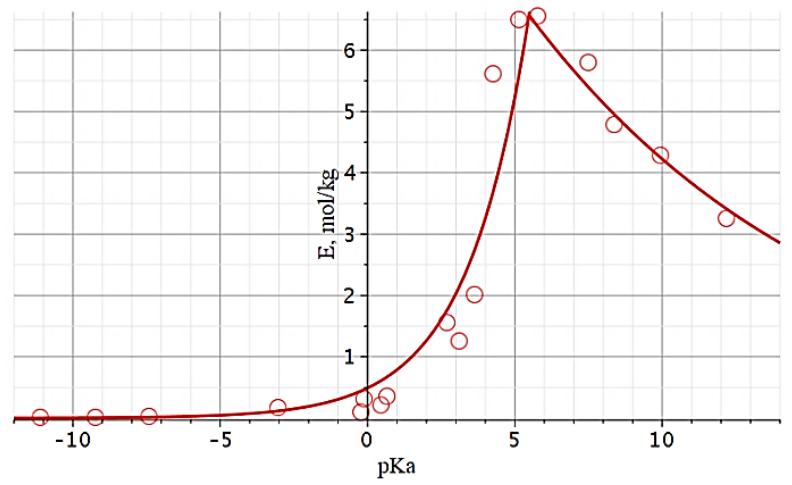

Рис. 12. Зависимость сорбции анионов различных кислот на ГОА с добавками 20 ат.\% ионов $\mathrm{Ti}^{4+}$ от рK $_{a}$ диссоциации последней стадии соответствующих кислот

Экспоненциальный характер зависимости емкости от $\mathrm{pK}_{a}$, последней стадии диссоциации соответствующей кислоты 
указывает на образование между сорбентом и ионом сорбтива более прочной связи, чем электростатическое взаимодействие. Прочность этой связи растет с уменьшением силы кислоты, анионы которой сорбируются. Этот эффект дополнительно подтверждает наши предположения относительно эффектов делокализации электронов при сорбции анионов на неорганическом анионообменнике. Исключение составляют: тетрабориая кислота (рК=9), аскорбиновая кислота $(\mathrm{pK}=11,8)$, фенол $(\mathrm{pK}=10.0)$ и этиленгликоль $(\mathrm{pK}=14,1)$. Это отклонение связано, видимо, с большими кинетическими затруднениями при сорбции указанных веществ анионитом вследствие влияния стерического фактора и малости констант их диссоциации.

Аналогичный эффект возрастания сорбции анионов с уменьшением силы их кислот был обнаружен при сорбции анионов подгруппы хрома на гидроксиде железа ${ }^{150}$. Авторы связывает этот эффект с различным состоянием сорбируемых ионов в водном растворе, а именно с наличием форм: $\mathrm{MeO}_{4}^{2-} ; \mathrm{HMeO}_{4}^{-}$и $\mathrm{Me}_{2} \mathrm{O}_{7}^{2-}$. При этом они считают, что частично протонированный ион $\mathrm{HMeO}_{4}^{-}$обладает наибольшей склонностью к сорбции на гидроксиде железа. Однако эта модель не объясняет хорошей сорбции анионов простых, одноосновных кислот, таких как муравьиная, уксусная, фенол и другие.

Для объяснения наблюдаемых эффектов можно предположить следующее. Как известно, рост величины $\mathrm{pK}$ диссоциации кислоты связан с увеличением энергии взаимодействия протона и кислотного остатка, что обусловлено возрастанием электронной плотности на связи Н-О. Поэтому вполне логичным предположением является возрастание степени ковалентности связи таких анионов с матрицей сорбента. Кроме того, дополнительный вклад в энергию образующейся ковалентной связи могут вносить вакантные d-подуровни катионов, образующих матрицу сорбентов.

На основе этих данных можно сделать вывод, что гидратированный оксид алюминия с добавками ионов $\mathrm{Ti}^{4+}$ можно использовать для синтеза анионитов, селективных к анионам, для которых соответствующие кислоты имеют высокие значения величины $\mathrm{pK}$ последней стадии диссоциации. Эти положения были

150 Копылова Н.В., Новиков А.И., Фокина Г.А., Назармадов И.Б. Исследование зависимости между состоянием анионов подгруппы хрома и сорбцией их гидроксидом железа (ІІІ). В сб.: Соосаждение с гидроксидами. Душанбе, 1977. Вып. 2. с. 65-71. 
практически использованы при синтезе неорганических анионообменников, в частности на основе смешанных гидратированных оксидов алюминия и титана.

Результаты проведенных экспериментов были использованы при разработке способов получения неорганических анионообменников на основе гидратированного оксида алюминия, легированного ионами $\mathrm{W}(\mathrm{VI}), \mathrm{Zr}(\mathrm{IV})$ и $\mathrm{Ti}(\mathrm{IV})$, которым присвоены условные символы соответственно ААВ-0, ААЦ-0 и ААТ-0 151,152,153,154,155. В таблице 3 приведены сравнительные характеристики данных сорбентов, полученные по результатам 5 циклов сорбции анионов из растворов 0,1 M HC1 и 0,05 $\mathrm{M} \mathrm{H}_{2} \mathrm{SO}_{4}$. Десорбцию поглощенных ионов осуществляли $0,1 \mathrm{M}$ раствором $\mathrm{NaOH}$. B таблице 3 представлена обменная емкость анионитов, по и $\mathrm{SO}_{4}{ }^{2-}$ ионам соответственно, $\left(E_{\mathrm{Cl}^{-}}, E_{\mathrm{SO}_{4}^{2-}}\right.$, моль/кг) и средние потери сорбента за 1 цикл работы $(\Delta \mathrm{m}$, масс. $\%)$.

Таблица 3

Сравнительные характеристики анионообменников на основе гидратированного оксида алюминия

\begin{tabular}{|c|c|c|c|}
\hline Анионообменник & $E_{\mathrm{Cl}^{-}}$ & $E_{\mathrm{SO}_{4}^{2-}}$ & $\Delta m, \%$ \\
\hline Гидратированный оксид алюминия & $2.0 \pm 0.1$ & $1.0 \pm 0.1$ & $2.2 \pm 0.3$ \\
\hline ААВ-0 & $4.3 \pm 0.2$ & $2.1 \pm 0.1$ & $1.6 \pm 0.2$ \\
\hline ААЦ-0 & $6.0 \pm 0.3$ & $3.1 \pm 0.2$ & $1.3 \pm 0.1$ \\
\hline ААТ-0 & $7.8 \pm 0.4$ & $3.9 \pm 0.2$ & $1.1 \pm 0.1$ \\
\hline
\end{tabular}

151 Кудрявцев П.Г., Онорин С.А., Вольхин В.В. Способ получения неорганического анионообменника. А.с. № 1125043 (СССР). Опубл. в Б. И. 1984. № 43. С. 33 .

152 Кудрявцев П.Г., Онорин С.А., Вольхин В.В. Способ получения неорганического анионообменника. А.с. № 1189497 (СССР). Опубл. в Б. И. 1985. № 41. С. 30 .

153 Кудрявцев П.Г., Онорин С.А., Вольхин В.В. Способ получения неорганического анионообменника. А.с. № 1274763 (СССР). Опубл. в Б. И. 1986. № 45. С. 28.

154 Кудрявцев П.Г. Онорин С.А. Способ получения неорганического анионообменника ААТ-1. А.С. СССР № 1435280 по заявке № 4227940 от 13.04 .87

155 Кудрявцев П.Г. Онорин С.А., Вольхин В.В. Способ получения неорганического анионообменника. А.С. СССР № 1435281 по заявке № 4228474 от 13.04 .87 
Представленные в таблице 2 данные показывают, что по сравнению с исходным гидратированным оксидом алюминия, легированные сорбенты имеют более высокую величину полной обменной емкости и лучшую химическую устойчивость.

Полученные выводы не ограничивается анионитами. Материалы на основе смешанных гидратированных оксидов различных элементов можно использовать и как носители для катализаторов. Их анионообменные свойства позволяют в широких пределах варьировать количество различных анионов, вводимое в твердую фазу, и, соответственно, регулировать число и состояние активных центров.

\section{ВЫВОДЫ}

Наиболее сильное влияние на строение и ионообменные свойства гидратированного оксида алюминия оказывает введение в его состав при осаждении ионов легирующих элементов. Изоморфное замещение части ионов Al(III) в структуре гидратированного оксида алюминия ионами с более высоким зарядом (Ti(IV), $\mathrm{Zr}(\mathrm{IV})$ или $\mathrm{W}(\mathrm{VI})$ ) приводит к увеличению содержания в получаемом материале обменных ОН-групп. Добавки ионов Ti(IV) к гидратированному оксиду алюминия приводят к росту беспорядка и к увеличению межслоевых расстояний в структуре синтезируемых материалов. За счет оптимизации состава материала удается существенно улучшить его сорбционные характеристики. Синтезированные на основе гидратированного оксида алюминия анионообменники ААВ-0, ААЦ-0 и ААТ-0 могут быть использованы для очистки слабокислых растворов электролитов от анионных примесей в динамическом режиме повторяющихся циклов сорбции - десорбции.

Представленные результаты позволяют сделать достаточно далеко идущие выводы, которые не ограничиваются синтезом неорганических анионитов. Материалы на основе смешанных гидратированных оксидов различных элементов можно использовать и как носители для катализаторов. Их анионообменные свойства позволяют в широких пределах варьировать количество различных анионов, вводимое в твердую фазу и, соответственно, регулировать число и состояние каталитических активных центров. 


\section{АННОТАЦИЯ}

Неорганические сорбенты по сравнению с обычными органическими ионитами обладают более высокой селективностью, радиационной, термической и химической устойчивостью. Неорганические ионообменники являются универсальными материалами, проявляющими как катионообменные, так и анионообменные свойства. В данной работе, на примере гидратированного оксида алюминия (ГОА), исследуется возможность расширения круга оксигидратов металлов, способных служить основой для получения неорганических анионообменных материалов. Свойства гидратированного оксида алюминия во многом зависят от способа его получения. Это явление связано с различным состоянием ионов $\mathrm{Al}^{3+}$ в водных растворах в процессе гидролиза. Наиболее сильное влияние на строение и ионообменные свойства гидратированного оксида алюминия оказывает введение в его состав при осаждении ионов легирующих элементов. Изоморфное замещение части ионов Al(III) в структуре гидратированного оксида алюминия ионами с более высоким зарядом (Ti(IV), $\mathrm{Zr}(\mathrm{IV})$ или $\mathrm{W}(\mathrm{VI}))$ приводит к увеличению содержания в получаемом материале обменных ОН-групп. Синтезированные материалы представляют собой аморфные вещества, для исследования их строения применялся метод диффузного рассеяния рентгеновских лучей. Определен структурный мотив гиббсита и проанализированы структурные изменения, происходящие под действием различных факторов и условий синтеза. За счет оптимизации состава материала удается существенно улучшить его сорбционные характеристики. Синтезированные на основе гидратированного оксида алюминия анионообменники ААВ-0, ААЦ-0 и ААТ-0 могут быть использованы для очистки слабокислых растворов электролитов от анионных примесей в динамическом режиме повторяющихся циклов сорбции-десорбции. Материалы на основе смешанных гидратированных оксидов различных элементов можно использовать и как носители для катализаторов. Их анионообменные свойства позволяют в широких пределах варьировать количество различных анионов, вводимое в твердую фазу и, соответственно, регулировать число и состояние каталитических активных центров. 


\section{ЛИТЕРАТУРА}

1. Хабаши Ф. Основы прикладной металлургии. Т. 2. Москва : Металлургия, 1975.

2. Иониты в химической технологии. Под ред. Никольского Б. П. и Романкова П.Г. Ленинград : Химия, 1982.

3. Лебедев К.В., Казанцев Е.Я., Розманов В.М. и др. Иониты в цветной металлургии. Москва : Металлургия, 1975.

4. Вольхин В.В., Леонтьева Г.В. Физико-химическое исследование ионообменных свойств двуокиси марганца. Известия АН СССР. Серия: Неорганические материальы. 1969. т. 5. № 7. C. 1224-19.

5. Амфлетт Ч. Неорганические иониты. Москва : МИР. 1966. $188 \mathrm{c}$.

6. Степин Б.Д. Методы получения особо чистых неорганических веществ. Ленинград : Химия, 1969.

7. Белинская Ф.А., Милицина Э.А. Неорганические ионообменные материалы на основе труднорастворимых соединений сурьмы (V). Успехи химии, 1980. т. 49. № 10. C. $1904-1936$.

8. Ходящев М.Б., Онорин С.А., Вольхин В.В. и др. Переработка твердых отходов производства оксида ванадия (V) из технического окситрихлорида ванадия. Цветные металльл. 1985. № 4. С. 66.

9. Ходяшев М.Б., Онорин С.А., Вольхин В.В. и др. Сорбционная очистка цинк-кадмиевых растворов от мышьяка. Цветные металлы. 1987. № 2. С. 22.

10. Кудрявцев П.Г., Онорин С.А., Вольхин В.В. Способ получения неорганического анионообменника. А.с. № 1125043 (СССР). Опубл. в Б. И. 1984. № 43. С. 33.

11. Кудрявцев П.Г., Онорин С.А., Вольхин В.В. Способ получения неорганического анионообменника. А.с. № 1189497 (СССР). Опубл. в Б. И. 1985. № 41. С. 30.

12. Кудрявцев П.Г., Онорин С.А., Вольхин В.В. Способ получения неорганического анионообменника. А.с. № 1274763 (СССР). Опубл. в Б. И. 1986. № 45. С. 28.

13. Кудрявцев П.Г. Онорин С.А. Способ получения неорганического анионообменника ААТ-1. А.С. СССР № 1435280 по заявке № 4227940 от 13.04.87. 
14. Кудрявцев П.Г. Онорин С.А., Вольхин В.В. Способ получения неорганического анионообменника. А.С. СССР № 1435281 по заявке № 4228474 от 13.04.87.

15. Muller D., D. Hoebbel D., Gessner W. 27Al NMR studies of aluminosilicate solutions. Influences of the second coordination sphere on the shielding of aluminium Chemical Physics Letters, Volume 84, Issue 1, 15 November 1981, Pages 25-29, doi:10.1016/00092614(81)85362-6.

16. Brown P.L., Ekberg C. Hydrolysis of Metal Ions. Volume 1-2, Wiley-VCH, 2016, 945 p. ISBN: 978-3-527-65621-9.

17. Wesolowski D.J., Palmer D.A. Aluminum speciation and equilibria in aqueous solution: V. Gibbsite solubility at $50^{\circ} \mathrm{C}$ and $\mathrm{pH}$ 3-9 in 0.1 molal $\mathrm{NaCl}$ solutions (a general model for aluminum speciation; analytical methods). Geochimica et Cosmochimica Acta, Vol. 58, No. 14, pp. 2947-2969, 1994. URL: https://doi.org/10.1016/00167037(94)90171-6.

18. Patterson H., Tyree Jr. S.Y. A light scattering study of the hydrolytic polymerization of aluminum. Journal of Colloid and Interface Science. Vol. 43, N 2, 1973, P. 389-398. URL: https://doi.org/10.1016/0021-9797(73)90385-8.

19. Patterson H., Tyree Jr. S.Y. A light scattering study of the hydrolytic polymerization of aluminum. Journal of Colloid and Interface Science. Vol. 43. N 2. 1973. P. 389-398. URL: https://doi.org/10.1016/0021-9797(73)90385-8.

20. Rausch W.V. and Bale H.D. Small angle X-ray scattering from hydrolyzed aluminum nitrate solutions: J. Chem. Phys. 1964. 40. 33913394. URL: https://doi.org/10.1063/1.1725011.

21. Matijević E., Mathai K.G., Ottewill R.H., Kerker M. Detection of Metal Ion Hydrolysis by Coagulation. III. Aluminum. J. Phys. Chem. 1961. 65. 5. 826-830. URL: https://doi.org/10.1021/j100823a028.

22. Van Cauwelaert, F. H., Bosmans, H. J. Polycations formed in the hydrolysis of the aluminum ion. J. Rev. Chim. Minerale. 1969. Vol. 6. No 3. p. 611-623.

23. Leonard A.J., Van Cauwelaert P., Fripiat J.J. Structure and properties of amorphous silicoaluminas. III. Hydrated aluminas and transition aluminas. J. Phys. Chem. 1967. V. 71. № 3. P. 695-708.

24. Wefers, K. Oxides and Hydroxides of Aluminum. Naturwissenschaflen, 49, 204-205 (1962).

25. Shafran, K.L., Deschaume, O., \& Perry, C.C. The static anion exchange method for generation of high purity aluminium 
polyoxocations and monodisperse aluminium hydroxide nanoparticles. Journal of Materials Chemistry. 2005. 15(33). 3415. doi:10.1039/b505466d.

26. Johansson, G. (1960) On the crystal structures of some basic aluminium salts. Acta Chem. Scand., 14, 771-773.

27. Bradley, S.M., Kydd, R.A., and Yamdagni, R. (2005) Study of the hydrolysis of combined $\mathrm{Al}^{3+}$ and $\mathrm{Ga}^{3+}$ aqueous solutions: formation of an extremely stable $\mathrm{GaO}_{4} \mathrm{Al}_{12}(\mathrm{OH})_{24}\left(\mathrm{H}_{2} \mathrm{O}\right)_{12}{ }^{7+}$ polyoxycation. Magn. Reson. Chem., 28, 746-750.

28. Roswell J. and Nazar L. F. Speciation and Thermal Transformation in Alumina Sols: Structures of the Polyhydroxyoxoaluminum Cluster $\left[\mathrm{Al}_{30} \mathrm{O}_{8}(\mathrm{OH})_{56}\left(\mathrm{H}_{2} \mathrm{O}\right)_{26}\right]^{18+}$ and Its $\delta$-Keggin Moiete. J. Am. Chem. Soc., 2000, 122, 3777. URL: https://doi.org/10.1021/ja993711.

29. Wade K. and Banister A. J., in 'Comprehensive Inorganic Chemistry', ed. J.C. Bailar, Jr., H.J. Emelcus, R. Nyholm and A.F. Trotman-Dickenson, Pergamon, Oxford, 1972, vol. 1, p. 993.

30. Липпенс Б.К., Стеггерда И.И. Активная окись алюминия. В кн.: Строение и свойства адсорбентов и катализаторов / Под ред. Б.Н. Линсена. Москва : Мир, 1973. с. 190-284.

31. Kudryavtsev P. Application of Methods of Statistical Thermodynamics for Modeling Equilibrium in Polyfunctional Ion-Exchangers. Journal "Scientific Israel-Technological Advantages" Vol. 21. no. 4. 2019. p. 49-74.

32. Casey W.H. Large Aqueous Aluminum Hydroxide Molecules. Chem. Rev. 2006, Vol. 106, №1, pp.1-16. URL: https://doi.org/10.1021/cr040095d.

33. Sato, T. (1972), The thermal transformation of Gelatinous Aluminium Hydroxide. Z. anorg. allg. Chem., 391: 167-173. doi: 10.1002/zaac.19723910210.

34. Брэг У.Л., Кларингоулл Г.Ф. Структура минералов. Москва : Мир, 1967. с. 390.

35. Megaw H.D. Dia Untersuehung der Strucktur A1(OH)3. Zeite. Krist., 1934. Bd.87. S. 185.

36. Petz J.I. Structure of Aluminum Hydroxide Gel, The Journal of Chemical Physics, 48, 909-911 (1968), DOI: http://dx.doi.org/10.1063/1.1668734.

37. Saalfeld H.L., Wedde M., Refinement of the crystal structure of gibbsite, $\mathrm{A} 1(\mathrm{OH}) 3$, Zeitschrift für Kristallographie - Crystalline 
Materials. Volume 139, Issue 1-6, Pages 129-135, ISSN (Online) 21967105, ISSN (Print) 2194-4946, DOI: 10.1524/zkri.1974.139.16.129.

38. Haycock D.E., Nicholls C.J., Urch D.S, Webber M.J., Wiech G. The electronic structure of magnesium dialuminium tetraoxide (spinel) using X-ray emission and X-ray photoelectron spectroscopies, J. Chem. Soc., Dalton Trans., 1978, 1785-1790, DOI: 10.1039/DT9780001785.

39. Fraas, L.M., Moore, J.E., Salzberg, J.B. Raman characterization studies of synthetic and natural $\mathrm{MgAl} 2 \mathrm{O} 4$ crystals, The Journal of Chemical Physics, Vol. 58, 3585-3592 DOI: http://dx.doi.org/10.1063/1.1679704.

40. Saine M.C., Husson E., Brusset H., Cerez de A. Etude vibrationnelle d'aluminates et de gallates de terres rares - III. Aluminates et gallates de structure grenat, Spectrochimica Acta Part A: Molecular Spectroscopy. Vol. 38. № 1. 1982. pp. 25-29.

41. Alemany L.B., Kirker G.W. 1. First observation of 5-coordinate aluminum by MAS aluminum-27 NMR in well-characterized solids, Journal of the American Chemical Society 1986108 (20). 6158-6162. DOI: $10.1021 /$ ja00280a008.

42. Barker M.G., Gadd P.G. and Michael J. BegleyM.J., Identification and characterisation of three novel compounds in the sodium-aluminium-oxygen system, J. Chem. Soc., Dalton Trans., 1984, N 6, p. 1139-1146, doi:10.1039/DT9840001139.

43. Kaduk J.A., Pei S., The Crystal Structure of Hydrated Sodium Aluminate, $\mathrm{NaAlO}_{2} \cdot 5 / 4 \mathrm{H}_{2} \mathrm{O}$, and Its Dehydration Product, Journal of Solid State Chemistry. Vol. 115. N 1. 1995. p. 126-139, doi:10.1006/jssc.1995.1111.

44. Ivanov-Emin B.N., Kazier G.Z., Ivleva V.I., Aksenova T.B. Russ. J. Inorg. Chem. (Engl. Transl.). 1981. 26. 295.

45. Glasser L.S.D., Giovanoli R. Barium aluminate hydrates. IV. The crystal structure of $\alpha-\mathrm{Ba} 2[\mathrm{~A} 14(\mathrm{OH}) 16]$, Acta Cryst. (1972). B28, 519-524, doi:10.1107/S0567740872002675.

46. Glasser L.S.D., Giovanoli R. Barium aluminate hydrates. V. The crystal structure of $\gamma-\mathrm{Ba}\left[\mathrm{AlO}(\mathrm{OH})_{2}\right]_{2}$, Acta Cryst. (1972). B28, 760-763. doi:10.1107/S0567740872003152.

47. Sabelli C., Ferroni R.T. The crystal structure of aluminite, Acta Cryst. (1978). B34, 2407-2412, doi:10.1107/S0567740878008341.

48. Vincent M.G., Jeffrey J.W. The crystal structure of pentacalcium trialuminate, $5 \mathrm{CaO} \cdot 3 \mathrm{Al}_{2} \mathrm{O}_{3}$, Acta Cryst. (1978). B34, 1422-1428 doi:10.1107/S0567740878005828. 
49. Kentgens A.P.M., Scholle K.F.M.G.J., Veeman W.S. Effect of hydration on the local symmetry around aluminum in ZSM-5 zeolites studied by aluminum-27 nuclear magnetic resonance, J. Phys. Chem., 1983, 87 (22), pp 4357-4360, DOI: 10.1021/j100245a008.

50. Пенкось Р., Алкоголяты алюминия. Успехи химии. 1968. т. 37. № 4. c. 647-676.

51. Ginderow, D. and Cesbron, F. (1979), Structure cristalline de l'aubertite, $\mathrm{AlCuCl}\left(\mathrm{SO}_{4}\right)_{2} \cdot 14 \mathrm{H}_{2} \mathrm{O}$. Acta Cryst. B, Vol. 35, pp. 2499-2502. doi: $10.1107 / \mathrm{S} 0567740879009766$.

52. Hermansson, K. (1983), A neutron diffraction determination of the structure of deuterated aluminium nitrate nonahydrate, A1 $\left(\mathrm{NO}_{3}\right)_{3} \cdot 9 \mathrm{D}_{2} \mathrm{O}$. Acta Crystallographica C, Vol 39:pp.925-930. doi: $10.1107 / \mathrm{S} 0108270183006897$.

53. Best S.P., Armstrong R.S., Beattie J.K. Vibrational spectroscopic studies of trivalent hexa-aqua-cations: single-crystal Raman spectra of caesium aluminium alums between 300 and $1200 \mathrm{~cm}^{-1}$, J. Chem. Soc., Dalton Trans., 1982, 1655-1664, DOI: $10.1039 / \mathrm{DT} 9820001655$.

54. Adams D.M., Hills D.J. Single-crystal Raman and infrared study of aluminium trichloride hexa-hydrate. J. Chem. Soc., Dalton Trans. 1978. 782-788. DOI: 10.1039/DT9780000782.

55. Pankratov A.V., Skachkov A.N., Shalaeva O.N., Kurbatov G.M. Russ. J. Inorg. Chem. (Engl. Transl.), 1972, 17, 47.

56. Kriutsov N.V., Shirokova G.N., Rosolovskii V.Ya. Russ. J. Inorg. Chem. (Engl. Transl.), 1973, 18, 503.

57. Teagarden, D.L., Radavich, J.F., White, J.L., Hem, S.L. Aluminum chlorohydrate II: Physicochemical properties, J. Pharm. Sci., 1981, Vol. 70, 7, 762-764, DOI: 10.1002/jps.2600700712.

58. Waters D.N., Henty M.S. Raman spectra of aqueous solutions of hydrolysed aluminium(III) salts, J. Chem. Soc., Dalton Trans. 1977. 243-245. DOI: 10.1039/DT9770000243.

59. Ohman L.-O., Forsling W., Equilibrium and Structural Studies of Silicon(IV) and Aluminium(III) in Aqueous Solution. 3. Potentiometric Study of Aluminium(III) Hydrolysis and Aluminium(III) Hydroxo Carbonates in $0.6 \mathrm{M} \mathrm{Na}(\mathrm{Cl})$. Acta Chem. Scand, Ser. A 1981. Vol. 35. pp. 795-802.

60. Müller D., Gessner W., Schönherr S., Görz H., Über basische Aluminiumsalze und ihre Lösungen. X. NMR-Untersuchungen am tridekameren Al-oxo-hydroxo-Kation, Z. anorg. allg. Chem., 1981, Vol. 483, 12, pp. 153-160, DOI: 10.1002/zaac.19814831219. 
61. Schönherr, S., Görz, H., Müller, D., Gessner, W. Über basische Aluminiumsalze und ihre Lösungen. VI. Darstellung und Charakterisierung eines wasserlöslichen Al13O40-Chlorides, Z. anorg. allg. Chem., 1981, Vol. 476, 5, pp. 188-194, DOI: $10.1002 /$ zaac.19814760522.

62. Schönherr, S., Görz, H., Gessner, W., Winzer, M., Müller, D. Über basische Aluminiumsalze und ihre Lösungen. VII. Zum Einfluß der Herstellungsbedingungen, der Konzentration und der Alterungszeit auf die Zusammensetzung von Lösungen basischer Aluminiumsalze, Z. anorg. allg. Chem. 1981, Vol. 476, 5, 195-200, DOI, 10.1002/zaac.19814760523.

63. Schönherr, S., Görz, H. Darstellung und Eigenschaften von Heteropolykationenverbindungen. I. Über das Dodekaaluminogermaniumsulfat $\left[\mathrm{GeO}_{4} \mathrm{Al}_{12}(\mathrm{OH})_{24}\left(\mathrm{H}_{2} \mathrm{O}\right)_{12}\right]\left(\mathrm{SO}_{4}\right)_{4} \cdot x \mathrm{H}_{2} \mathrm{O}$, Z. anorg. allg. Chem., 1983, Vol. 503, 8, pp. 37-42, DOI: 10.1002/zaac.19835030805.

64. Lampe, F., Müller, D., Gessner, W., Grimmer, A.-R., Scheler, G. Über basische Aluminiumsalze und ihre Lösungen. XI. Vergleichende ${ }^{27}$ Al-NMR-Untersuchungen am Mineral Zunyit und basischen Aluminium-Salzen mit tridekameren Al-oxo-hydroxo-aquo-Kationen, Z. anorg. allg. Chem., 1982, Vol. 489, 1, pp. 16-22, DOI: $10.1002 /$ zaac. 19824890104.

65. Schönherr, S., Görz, H., Bertram, R., Müller, D., Gessner, W. Über basische Aluminiumsalze und ihre Lösungen. (XII). Vergleichende Untersuchungen an unterschiedlich dargestellten Basischen Aluminiumchloridlösungen, Z. anorg. allg. Chem., 1983, Vol. 502, 7, pp. 113-122, DOI: 10.1002/zaac.19835020715.

66. Brand, P., Seltmann, U. Über basische Aluminiumsalze und ihre Lösungen. (XIII). Kristalline basische Aluminiumchloride als Produkte der Rehydratisierung und Hydrochlorierung von Übergangstonerden, Z. anorg. allg. Chem., 1983, Vol. 502, 7, pp. 123-131, DOI: 10.1002/zaac.19835020716.

67. Brand, P., Seltmann, U., Müller, D., Büchner, U. Über basische Aluminiumsalze und ihre Lösungen. XIV. Zur Strukturellen Funktion des Wassers in basischen Aluminiumchloriden, Z. anorg. allg. Chem., 1983, Vol. 502, 7, 132-140, DOI: 10.1002/zaac.19835020717.

68. Schönherr, S., Bertram, R., Görz, H. Über basische Aluminiumsalze und ihre Lösungen. XVI. Kinetische Untersuchungen an niederbasischen Aluminiumchloridlösungen, Z. anorg. allg. Chem., 1983, Vol. 503, 8, pp. 193-200, DOI: 10.1002/zaac.19835030820. 
69. Kühling, M., Röbisch, G., Kinetische Untersuchungen zum Abbau von Al13O40-Kationen durch Salzsäure, Z. anorg. allg. Chem., 1991, Vol. 603, 1, pp. 137-143, DOI: 10.1002/zaac.19916030118.

70. Mesmer R.E., Baes C.F., Jr. Acidity measurements at elevated temperatures. V. Aluminum ion hydrolysis, Inorg. Chem., 1971, 10 (10), pp 2290-2296, DOI: 10.1021/ic50104a040.

71. Moolenaar R.J., Evans J.C., McKeever L.D. J. Phys. Chem. 1. Structure of the aluminate ion in solutions at high $\mathrm{pH}$. The Journal of Physical Chemistry 197074 (20), 3629-3636, DOI: 10.1021/j100714a014.

72. Szabó, Z. G., Wajand, J., Ruff, I. and Burger, K. (1978), Investigation of Aluminate Solutions by water activity measurement. $Z$. anorg. allg. Chem. 441: 245-251. doi: 10.1002/zaac.19784410128.

73. Akitt J.W., GessnerW. Aluminium-27 nuclear magnetic resonance investigations of highly alkaline aluminate solutions. J. Chem. Soc. Dalton Trans. 1984. pp. 147-148. DOI: 10.1039/DT9840000147.

74. McIntyre J.F., Foley R.T., Brown B.F. Ultraviolet spectra of aluminum salt solutions. Inorg. Chem. 1982, 21 (3), pp. 1167-1172, DOI: 10.1021/ic00133a056.

75. Veillard H. Hydration of the cation's aluminum (3+) and copper. A theoretical study. J. Am. Chem. Soc. 1977, 99 (22), pp 7194-7199, DOI: $10.1021 / \mathrm{ja} 00464 \mathrm{a} 016$.

76. Hill R.J., Gibbs G.V., Peterson R.C., A Molecular Orbital Study of the Stereochemistry of Pentacoordinated Aluminium, Aust. J. Chem. 1979. Vol. 32. pp. 231-241. http://dx.doi.org/10.1071/CH9790231.

77. Gropen O., Johansen R., Haaland A., Stokkeland O. Ab initio molecular orbital calculations on $\mathrm{H}_{3} \mathrm{AlOH}_{2},\left(\mathrm{H}_{2} \mathrm{AlOH}\right)_{2}$, and some related species, Journal of Organometallic Chemistry, Vol. 92, 2, 1975, Pages 147-156, http://dx.doi.org/10.1016/S0022-328X(00)92083-7.

78. Hange R.H., Kaufman J.W., Margrave J.L. Infrared matrixisolation studies of the interactions and reactions of Group 3A metal atoms with water. J. Am. Chem. Soc. 1980, Vol. 102, 19, 6005-6011.

79. Дзисько В.А., Карнаухов А.П., Тарасова Д.В. Физикохимические основы синтеза окисных катализаторов. Новосибирск : Наука, 1978. 384 с.

80. Желиговская Н.Н., Черняев И.И. Химия комплексных соединений, Москва : Мир, 1979. 568 с.

81. Химия и технология редких и рассеянных элементов, ч. II, Под ред. К.А. Большакова, Изд.2-е, Москва : Высшая Школа, $1976.360 \mathrm{c}$. 
82. Криворучко О.П., Буянов Р.А. Развитие теории кристаллизации малорастворимых гидроксидов и ее применение в научных основах приготовления катализаторов. Всесоюзная школа по катализаторам / ИК СО АН. Новосибирск, 1982. С. 122-150.

83. Saukkoriipi, Jaakko, Theoretical study of the hydrolysis of aluminum complexes. Faculty of Science, Department of Chemistry, University of Oulu, Acta Univ. Oul. A 554, 2010, 90 p.

84. Скрышевский А.Ф. Структурный анализ жидкостей и аморфных тел. Москва : Высшая школа, 1980.

85. Татаринова Л.И. Электронография аморфных тел. Москва : Наука, 1972. 102 с.

86. Лурье Ю.Ю. Справочник по аналитической химии. Москва : Химия, 1965.

87. Онорин С.А., Вольхин В.В., Ходяшев М.Б., Сесюнина Е.А., Алпатова Е.В. Свойства композиционных титансодержащих сорбентов. Межвузовский сборник научных трудов: Химия и технология неорганических сорбентов. Пермь : 1989. С. 124-129.

88. Дей К., Селбин Д. Теоретическая неорганическая химия. Москва : Мир, 1969. 432 с.

89. Вайнштейн Б.К., Фридкин В.М., Инденбом Р.Л. Современная кристаллография. 2 том. Структура кристаллов. Москва : Наука, 1979. 359 с.

90. Рабинович Р.А., Хавин 3.Я. Краткий химический справочник. Ленинград : Химия, 1977. 376 с.

91. Van Cauwelaert, F.H., Bosmans, H.J. Polycations formed in the hydrolysis of the aluminum ion. J. Rev. Chim. Minerale. 1969. Vol. 6. No 3. p. 611-623.

92. Fripiat J.J., Van Cauwelaert F.H., Bosnians H.I. Structure of aluminum cations in agueous solutions. J. Phys. Chem. 1965. Vol. 69, N. 7. P. 2458-2461.

93. Schofield, R.K., \& Taylor, A.W. The hydrolysis of aluminium salt solutions. Journal of the Chemical Society (Resumed). 1954. p. 4445-4448. doi:10.1039/jr9540004445.

94. Пятенко Ю.А., Воронков А.А., Пудовкина 3.В. Минералогическая кристаллохимия титана. Москва : Наука. 1976. $155 \mathrm{c}$.

95. Kudryavtsev P. Dissociation Constants of Hydrated Oxides of chemical elements in the D.I. Mendeleev Periodic System. Journal "Scientific Israel-Technological Advantages" Vol. 21. no. 5-6. 2019. p. $38-81$. 
96. Нефедов В.Н. Взаимное влияние лигандов в соединениях переходных и непереходных элементов. В сб.: Трансвлияние в химии координационных соединений. Серия «Проблемь координационной химии». Москва : Наука, 1979. с. 73.

97. Маррел Дж., Кеттс С., Теддер Дж. Химическая связь. Москва : МИР, 1980. 382 с.

98. Шальве О., Додель Р., Дине С., Мальрьё Ж.-П. Локализация и делокализация в квантовой химии. Атомы и молекульы в основном состоянии. Москва : МИР, 1978. $414 \mathrm{c.}$

99. Ормонт Б.Ф. Введшие в физическую химию и кристаллохимию полупроводников. Изд. 2-е. Москва : Высшая школа, 1973. 655 с.

100. Копылова Н.В., Новиков А.И., Фокина Г.А., Назармадов И.Б. Исследование зависимости между состоянием анионов подгруппы хрома и сорбцией их гидроксидом железа (III). B сб.: Соосаждение с гидроксидами. Душанбе, 1977. Вып. 2, с. 65-71.

\section{Information about author:} Kudriavtsev P. H., Professor,

Deputy Director for Research and Development Polymate Ltd-Israel Nanotechnology Research Center 73, Migdal HaEmek 2310001, Haifa, Israel 